\title{
The Residential Architecture of Ankara during the 1920s: The Housing Types in the Settlement Zones of the New Capital City
}

\author{
1920’lerde Ankara’nın Konut Mimarisi:Yeni Başkentin Yerleşim \\ Bölgelerinde Konut Tipleri*
}

\section{Deniz AVCI HOSANLI}

Dr., Part-time Instructor, Department of Interior Architecture and Environmental Design, Bilkent University, Ankara, Turkey avci.deniz@yahoo.com

\section{T. Elvan ALTAN}

Prof., Middle East Technical University, Department of Architecture, Ankara, Turkey

tomris@metu.edu.tr

DOI: $10.5505 /$ jas.2018.08108

\begin{abstract}
The focus of this paper is the residential architecture of the capital city Ankara during the 1920s, which is investigated as part of the development of the city after the foundation of the Turkish Republic. It initially defines the main settlement zones of contemporary Ankara that transformed and were formed in relation with the contemporary development plans implemented to direct the urban growth. The construction of new single houses and apartments as the main housing types of the period in the defined settlement zones of the historical and the developing parts of the city is then analyzed in order to understand how the increase in population and the resultant housing need in the new capital city affected the change in its built environment. In this frame of analysis, the paper aims to evaluate the new housing production during the first decade of the capital city Ankara by examining the old city-Ulus that transformed and the new city-Yenişehir that was formed in this process, and also considering the simultaneous un-planned transformation of the vineyards and formation of shed-houses in the peripheries of the city center.
\end{abstract}

Keywords: Ulus-Yenişehir, Residential architecture, Early Republican architecture, the 1920s, Ankara

\section{Öz}

Makale, başkent Ankara'nın 1920’lerde üretilen konut mimarlığına odaklanmakta ve bu üretimi, kentin Türkiye Cumhuriyeti'nin kuruluşu sonrasındaki gelişiminin bir parçası olarak incelemektedir. Makalede öncelikle Ankara'nın kentsel büyümesini yönlendirmek için uygulamaya konan gelişme planlarıyla ilişkili olarak dönüşen ve oluşturulan ana yerleşim bölgeleri tanımlanmaktadır. Ardından, nüfus artışı ve dolayısıyla ortaya çıkan konut ihtiyacının, yeni başkentin yapılı çevresindeki değişimi nasıl etkilediğini anlamak için, dönemin ana konut tipleri olarak yeni tekil konut ve apartmanların kentin tarihi ve gelişen kısımlarının tanımlanan yerleşim bölgelerindeki inşası irdelenmektedir. Bu analiz çerçevesinde, başkent Ankara'nın ilk on yılında gerçekleştirilen yeni konut üretimini, bu süreçte dönüşen eski şehir-Ulus ile oluşturulan Yenişehir'i inceleyerek ve kent merkezinin çeperlerinde yer alan bağlar bölgesinin eşzamanlı dönüşümü ile barakaların oluşumunu da göz önüne alarak değerlendirmeyi hedeflemektedir.

Anahtar sözcülkler: Ulus-Yenişehir, Konut mimarisi, Erken Cumhuriyet dönemi mimarlığı, 1920’ler, Ankara

* This paper is part of the doctorate dissertation by Deniz Avcı Hosanlı titled "Housing the Modern Nation: The Transformation of Residential Architecture in Ankara during the 1920s" (METU Graduate Program in Architectural History, 2018; Supervisor: Prof. Dr. T. Elvan Altan).

** Bu makale, Deniz Avcı Hosanlı tarafından, ODTÜ Mimarlık Fakültesi Mimarlık Tarihi Programında Prof. Dr. Elvan Altan danışmanlığında gerçekleştirilen "Housing the Modern Nation: The Transformation of Residential Architecture in Ankara during the 1920s" başliklı doktora tezine dayandırılarak hazırlanmıştır. 


\section{Introduction}

In the early years of the Turkish Republic founded in 1923, every aspect of life in the new capital city Ankara, from urban and rural planning to architecture, to housing and even to interior furnishings, was interrelated to the nation-building and modernization processes of the new state. A search for the planned growth of the city was at the heart of these processes, and housing production was also a significant part of this undertaking. Improving the physical condition in the city initially required administrative and legal efforts to base planning, leading to the establishment of the Ministry of Population Exchange, Public Works and Settlement (Mübadele, İmar ve Issan Vekaleti) on October 23, 1923. In order to control the development and urbanization of Ankara, a document was proposed in 1924 by the Ministry, indicating the problems and the priorities of the construction industry (Cengizkan, 2009, p. 24). One of the most urgent issues was the problem of shelter and construction of houses, emphasized in article 6 as the aim of "meeting the housing shortage through the construction of new dwellings". Thus, the first urban development plans of Ankara were prepared by a member of the Istanbul Construction Commission, German architect Dr. Carl Christopher Lörcher (1884-1966), one in 1924 for the old city-Ulus, and the other in 1925 for the New City-Yenişehir. ${ }^{1}$ These development plans prepared the basis for the growth of Ankara in the first decade of the Republic until a competition was organized in order to bring out a more comprehensive plan in $1927 .^{2}$ Towards the end of the 1920s, the built environment of Ankara provided a certain level of comfort required in a capital city of a modern nation-state. ${ }^{3}$

The construction of public facilities affected this change; and residential architecture produced by public and private initiatives were simultaneously realized to answer the increasing demand. As contemporary public buildings, the newly constructed residential buildings of the 1920s became symbolic of the period's ideological approaches, being "historical-traditional" in appearance, i.e. exemplary buildings of the so-called "First National Style" with the use of elements as wide eaves, arched windows and facade decorations (Sözen, 1984; Aslanoğlu, 2010; Bozdoğan, 2012), while also using "contemporarymodern" construction technology and materials and having modernized interiors in line with the new lifestyle in the new state. This paper aims to analyze the contemporary residential architecture beyond these seemingly dichotomous frames of stylistic, technological and spatial features of single buildings by examining the new housing production as a part of the urban growth of Ankara during the first decade of the Republic.

Multiple processes of housing provision were witnessed to answer the needs of the newcomers to Ankara after it had become the capital city. One instant solution was the use of traditional residential buildings in the historical city center and the vineyards for rent. However, the old fabric of the city provided limited accommodation, and it was indeed unable to meet the required comfort for state officers and foreign diplomats. The second solution thus emerged as the newcomers started to buy and transform the traditional houses. This led to the increase in the value of lands and the price of existing houses as speculators started to trade them (Sarığlu, 2001, p. 33). The final and more comprehensive solution was the construction of new houses and apartments by public and private initiatives. This process initially started in the "old city", and then constructions moved on to its periphery where a "new city" was eventually constructed. Thus, the new character of the built environment in the new capital Ankara was created also by the help of the new housing constructions, although the simultaneous emergence of shed-houses disrupted the overall process of the modernization of the city.

Although the old city, where governmental functions were also located, continued to be the center of Ankara, covering nearly one third of the whole city even at the beginning of the 1930s (Mamboury, 1933, pp.136-137; Mıhçığlu Bilgi, 2010, p. 96), the unfavorable status of construction sites there during the 1920s shaped the development of the new capital city towards the south. ${ }^{4}$ New housing in the capital city accordingly developed from the old city-Ulus to the new city-Yenişehir, and from there spread towards the Çankaya region further in

1 For further information about Lörcher's plans, see: Cengizkan, 2004.

2 The plan by German architect Hermann Jansen was chosen in this competition and implemented from 1932 onwards. See: Tankut, 1993.

3 The end of the 1920s is generally taken in historiography as a turning point in terms of the development of the built environment in Ankara. See, for example: Batuman, 2017.

4 The growth towards the south could have been affected by the existence of the physical obstacles of the Hatip Stream (Bentderesi) and steep lands in the north and the east of the city. 
the south. Thus, contemporary housing in Ankara took place in three settlements zones that were mainly formed of the old city (the historic city center, the citadel and its skirts, i.e. the area named as Ulus during the Republican period) and the new city (Yenişehir, the newly developed area towards to the south, to Çankaya) - both planned by Lörcher in 1924 and 1925 respectively, together with the unplanned areas (vineyards, shed-housing areas, and Cebeci in between the old city and the new city) (Table I; Figure 1A ve1B).

Table I: Settlement Zones in Ankara during the 1920s.

\begin{tabular}{|c|c|c|c|c|}
\hline \multicolumn{5}{|c|}{ THE OLD CITY - ULUS } \\
\hline a & b & c & $\mathrm{d}$ & e \\
\hline $\begin{array}{l}\text { Karaoğlan Quarter, } \\
\text { Taşhan Square }\end{array}$ & $\begin{array}{l}\text { Hacibayram Quarter, } \\
\text { İsmet Pașa Quarter } \\
\text { Attf Bey Quarter }\end{array}$ & $\begin{array}{l}\text { Anafartalar Quarter, } \\
\text { 1916 Fire Area }\end{array}$ & $\begin{array}{l}\text { Samanpazan Quarter, } \\
\text { Hamamonnü Quarter, } \\
\text { Gündoḡdu Quarter }\end{array}$ & $\begin{array}{l}\text { Istiklal Quarter, } \\
\text { Youth Park Quarter }\end{array}$ \\
\hline 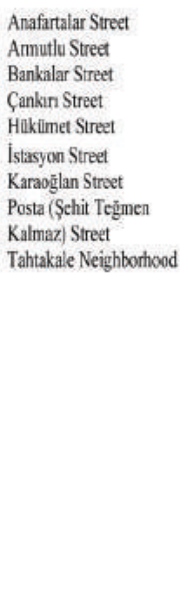 & $\begin{array}{l}\text { Bentderesi Street } \\
\text { Bent Street } \\
\text { Bostacilar Street } \\
\text { Çamhlca (Yaylk) Street } \\
\text { Gaziantep Street } \\
\text { Hact Bayram Street } \\
\text { Telgraf Street } \\
\text { Ulucak Street }\end{array}$ & 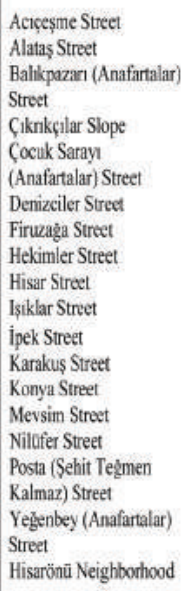 & $\begin{array}{l}\text { Dumlupinar Street } \\
\text { Fidan Street } \\
\text { Gīndoğdu Street } \\
\text { Talatpeşa Boulevard }\end{array}$ & $\begin{array}{l}\text { Bankalar Street } \\
\text { Gazi Mustafa Kemal } \\
\text { (Atatírk) Boulevard } \\
\text { Istiklal Stroct } \\
\text { Station Street } \\
\text { Talatpaşa Boulevard }\end{array}$ \\
\hline \multicolumn{3}{|c|}{ THE NEW CITY - YENIŞEHIR } & \multicolumn{2}{|c|}{3 UN-PLANNED AREAS } \\
\hline a & b & C & a & b \\
\hline $\begin{array}{l}\text { Sihhıye Square - } \\
\text { Havuzbaşı Square }\end{array}$ & $\begin{array}{l}\text { Havuzbaşı Square - } \\
\text { Ministries Quarter }\end{array}$ & $\begin{array}{l}\text { Ministries Quarter - } \\
\text { Cankaya }\end{array}$ & Vineyards & Shed-Housing Areas \\
\hline 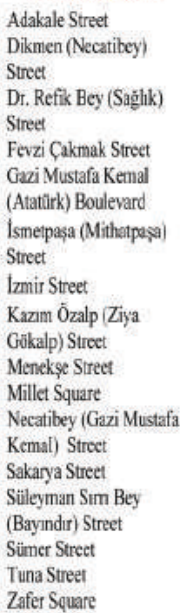 & 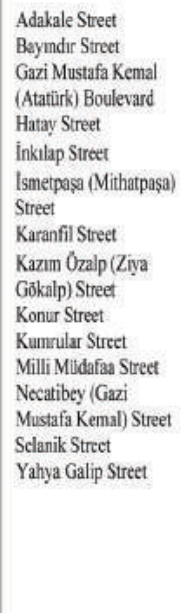 & $\begin{array}{l}\text { Gazi Mustafa Kemal } \\
\text { (Atattirk) Boulevard }\end{array}$ & $\begin{array}{l}\text { Cankaya, Dikmen, Esat, } \\
\text { Etlik, Keçiören }\end{array}$ & Akköprü, Cebeci \\
\hline
\end{tabular}




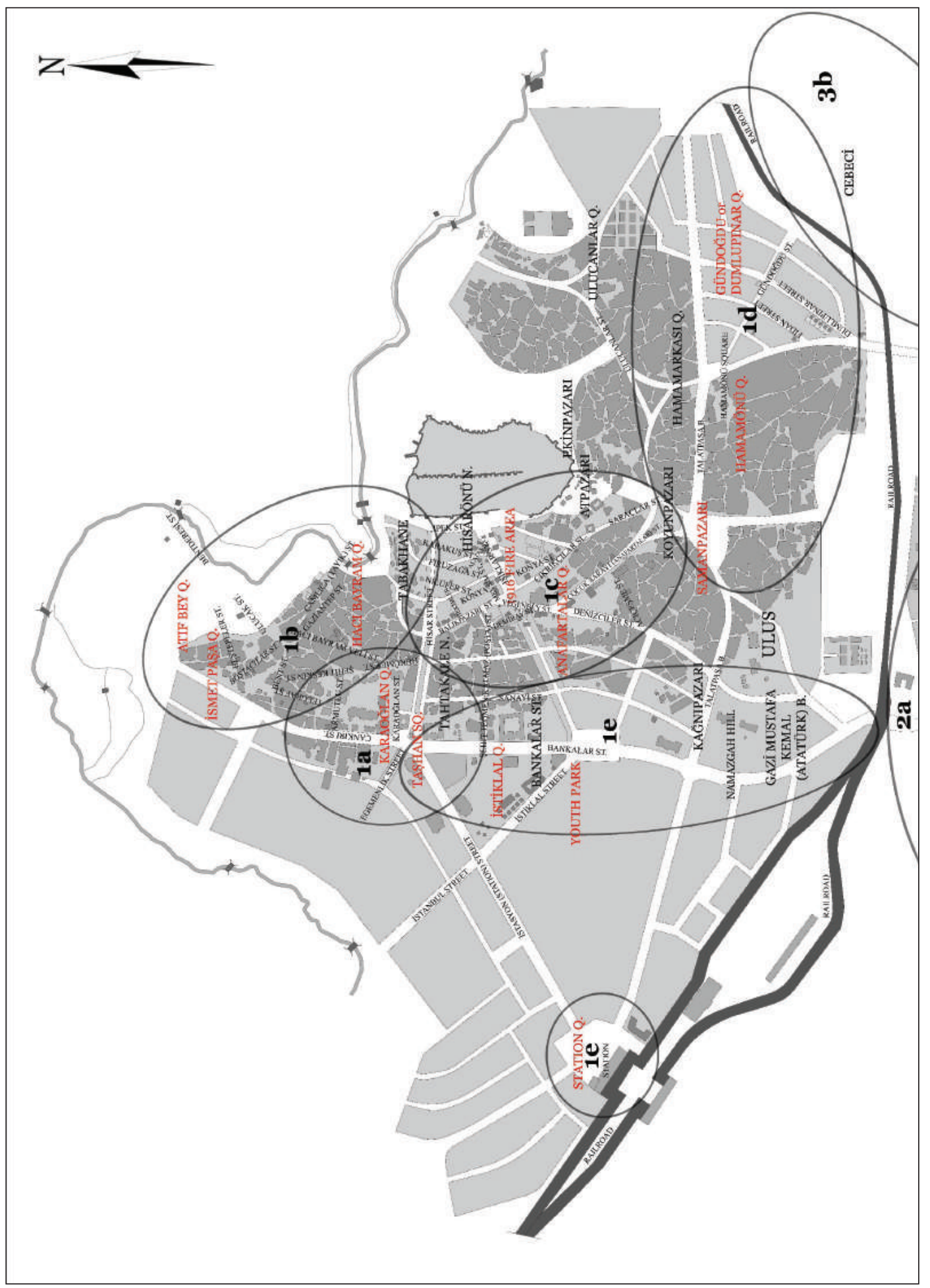

Figure 1A. Settlement Zones in Ankara during the 1920s I: The old city-Ulus.

Source: Prepared by the authors by merging 1924 Ankara Plan, Lörcher's (1924-1925) and Jansen’s (1928-1930) Ankara Plans and the current Ankara Map (2016-2017). 


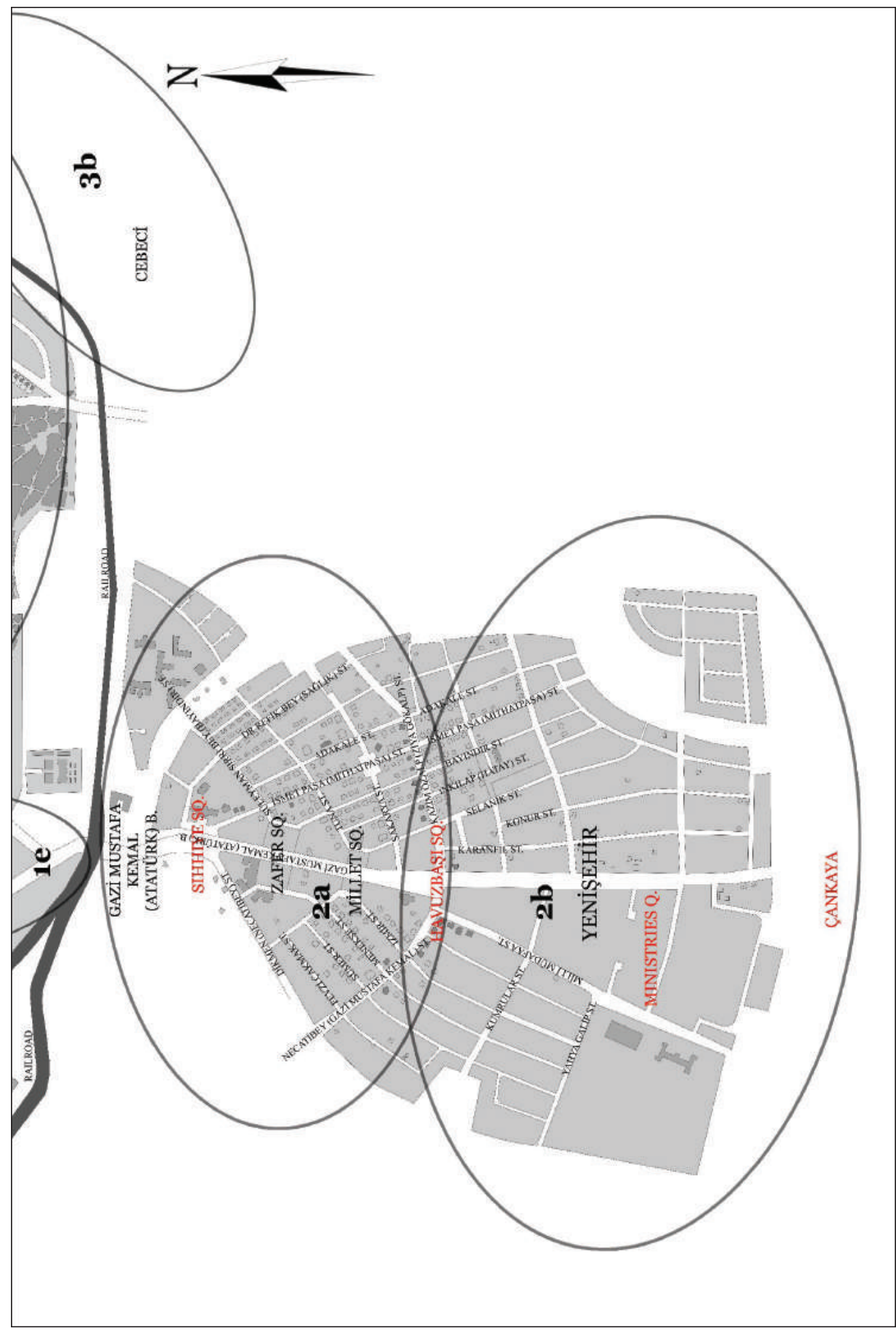

Figure 1B. Settlement Zones in Ankara during the 1920s II: The New City-Yenişehir.

Source: Prepared by the authors by merging 1924 Ankara Plan, Lörcher's (1924-1925) and Jansen’s (1928-1930) Ankara Plans and the current Ankara Map (2016-2017). 
The fast construction of residential buildings thus started in the 1920s, transforming the existing neighborhoods and forming new neighborhoods; and the examples of the decade set the housing types that would also shape Ankara's built environment in the following couple of decades. In addition to the "shed-houses" that were less in number at the time, the housing types of this period in Ankara could be divided into two main groups as "traditional" and "new". The traditional housing consisted of the existing residential architecture of the historic city and the vineyard houses, as well as the new buildings constructed in traditional ways (in terms of formal characteristics, materials, usage scheme, etc.). The life went on in these houses mostly as it had always been prior to Ankara's transformation into a capital city. The life standards of modernization could only be achieved with the maintenance of and alterations to traditional residential architecture; however, this required a considerable financial resource. As a result, "new" housing as single houses and apartments emerged in the available areas within the old city as well as the developing neighborhoods in the new city.

This paper focuses on the new housing production in Ankara during its first decade as the new capital city. ${ }^{5}$ Aiming to broaden the knowledge on the housing production in Ankara during the early years of the Republic, it analyzes the types of contemporary houses and apartments, for which partial documentation could be obtained from the Ankara Municipality, Ministry of Culture Department of Cultural and Natural Assets, and the VEKAM archives, and information about some of the examples could only be identified during the site surveys executed in Ulus, $\mathrm{K}_{1-}$ zulay, and Cebeci regions by the author. Among a total of 126 housing examples that could be documented, this article uses those chosen as representative of the housing types that were typical of the settlement zones in the city, ${ }^{6}$ and evaluates the new housing production in relation to the transformation of the old city and the formation of the new city in accordance with the contemporary development plans, also considering the simultaneous unplanned transformation of vineyards and the formation of shed-houses in the peripheral areas of the city.

\section{The Transformation of the Old City}

The old city of Ankara ${ }^{7}$ was formed of two main parts called the yukarı yüz ("Upper Face/Area Above") and the aşağı yüz (the lower face/area below), defined with reference to their location in relation to the citadel that is situated on a hill. At the beginning of the twentieth century, the traditional residential areas within the old city were still in use and their boundaries had been mostly preserved since the seventeenth century (Tunçer, 2014 , p. 24). On the other hand, the historic city had already surpassed its original boundaries during the late period of the Ottoman Empire with the construction of public buildings in the aşağı yüz part of the city such as the Governor's House (Hükümet Konă̆l), the Headquarters of the Party of Union and Progress (Ittihat ve Terakki Partisi) that was in power at the first decades of the twentieth century, Public Debt Administration building (Düyun-u Umumiye), schools, a hospital, and most significantly the Train Station, as well as with the formation of a new neighborhood for immigrants, the Boşnak Neighborhood, at the southern border of the old city. The new state chose the party headquarters building as the National Assembly building and immediately started to construct new public buildings around it. Thus, Taşhan Square (soon renamed as Hakimiyet-i Milliye [National Sovereignty], and then as Ulus [Nation]), at the corners of which the National Assembly building and Millet Bahçesi (Nation Garden) were located, turned into the center of the new capital city of Ankara, and the new constructions of the Republican period mainly took place around this center in the west of the old city, also transforming the close traditional neighborhoods.

As a result, the Karaoğlan quarter and the surroundings of Taşhan Square in its center witnessed the initial transformations in the new capital city. Around Taşhan Square, many public buildings for administrative, financial, and educational purposes, such as ministries, banks, schools, and museums were constructed. From Taşhan Square to the north, the area between Çankırı, Hükümet (Government) and Armutlu Streets, developed as the Ministeries (Vekaletler) Quarter, i.e. the

5 Conventional architectural historiography generally focuses on "important" public buildings designed by "important" architects. See: Altan Ergut, 2014. Similarly, studies on the newly produced residential architecture of the 1920s in Ankara in a wider frame of analysis are still limited, and they mainly contribute to the understanding of the apartment construction as a new architectural solution to answer the increasing housing demand. Especially see: İnce Güney and Wineman, 2008; Nalbantoğlu, 1981. For a recent and comprehensive study on the housing of the period between 1930 and 1980 in Ankara, see: http://sivilmimaribellekankara.com.

6 The final inventory of the residential architecture of the period in Ankara was prepared as part of the author's doctoral study.

7 For further information on the spatial characteristics of Ankara before the Republican period, see: Acar, 1975; Aktüre, 1987. 
administrative center of the city. To the south, the main boulevard of the city was named as Banks (Bankalar) Street, where headquarters of the banks were located, making the area also the financial center (Altan Ergut, 2005). ${ }^{8}$ In addition, all the main roads were connected at Taşhan Square, and many "han"s, hotels, and shops were located on them contributed to the commercial function of the area ${ }^{9}$ as well as providing the necessary places to meet the contemporary social needs of the citizens. The Taşhan building (1888) was the most significant among them as a traditional "han" functioning at the time as one of the most important hotels of Ankara. The upper class of the city spent their time mostly in the triangular area of the National Assembly, the newly constructed Ankara Palas Hotel on İstasyon Street close to the assembly building and the Karpiç Restaurant located at the ground floor of Taşhan (Aydın, Emiroğlu, Türkoğlu, and Özsoy, 2005, p. 403). Taşhan Square thus became the important connection point of the public areas with the traditional residential areas of the Karaoğlan quarter.

The new regime gave great importance to Taşhan Square by reorganizing its surroundings for properly representing the center of the new capital city. After 1924, with the establishment of the Municipality (Şehremaneti) of Ankara, regulations regarding the expropriation of lands were accepted by the Assembly. ${ }^{10}$ Accordingly, the old neighborhoods close to the new center of the city were re-planned by undertaking infrastructural works such as the widening of and the installment of sewers and asphalt/sidewalk pavements at Karaoğlan Street, Station (İstasyon) Street, and Anafartalar Street (Aydın, et al., 2005, pp. 384-385).
After the preparation of the Map of Ankara also in 1924 by the Map Department of National Defense (Müdafaa-i Milliye Harita Dairesi), more comprehensive urbanization decisions were taken (Günel and Kılc1, 2015; Dinçer, 2014, p.42). The government generally avoided the demolition and reconstruction of the old buildings in the historic area ${ }^{11}$, however, Lörcher's plan of the same year for the old city that proposed the widening of existent roads and the opening of new streets accelerated the change in the traditional fabric (Cengizkan, 2009, p.37). In line with such operations, ${ }^{12}$ the built environment of those traditional areas of the Karaoğlan, Hacıbayram, İsmet Paşa and Atıf Bey quarters, covering the north and south of the new center, started to transform (Table I; Figure 1A and $1 \mathrm{~B})$.

In the south of Taşhan Square, where traditional commercial activities continued to take place extending from the neighboring areas of the citadel to the Tahtakale neighborhood with the important Haydarpaşa Han (Sulu Han, 1511) and the Tahtakale Han (beginning of the sixteenth century) (Tunçer, 2014, p.19), the empty lands suitable for new constructions were immediately appropriated. Three of the known apartments of the Karaoğlan quarter were those used as the Erzurum Hotel, the Avrupa Hotel and a third apartment used as an addition to the Avrupa Hotel (Figure 2A and 2B). Being in the crowded center of the old city, these apartments were built as attached and semi-detached to their surrounding buildings. In the north of the square (Table I; Figure $1 \mathrm{~A}$ and $1 \mathrm{~B})$, new residential buildings also started to be constructed in the early years of the Republic. Those located close to the center, thus in crowded areas, were

8 The buildings of the Agriculture Bank (Ziraat Bankası) (Mongeri, 1926), Ottoman Bank (Osmanlı Bankası) (Mongeri, 1926), İş Bank (Mongeri, 1929), the Ministry of Education (Maarif Vekaleti, Koyunoğlu, 1927), the General Directorate of Post and Telegraph (Büyük Postane, 1925), and the Directory of State Monopoly (Tekel) (Mongeri, 1928) were located here.

9 The main commercial lines in the old city of the 1920s were: Ulus-Station (İstasyon Street), Ulus-Çankaya (Gazi Mustafa Kemal Boulevard), Karaoğlan-Hacıbayram (Hacı Bayram, Hükümet and Çankırı Streets), Ulus-Samanpazarı (Anafartalar Street), Samanpazarı-Station and Samanpazar1-Cebeci (Talatpaşa Boulevard), and Adliye (Courthouse)-Gureba (Numune) Hospital (Denizciler-Bahriyeliler Street). See: Dinçer, 2014, p.40.

10 With the regulation numbered 583 and dated March 24, 1925, 400 hectares of lands at the south of the old city was expropriated. Cengizkan states that this was established with the Lörcher Plan simultaenously (Cengizkan, 2004, p.47).

11 From the early years of the Republic onwards, there emerged an interest in the traditional houses of Ankara. See: Galip, 1926; Koyunoğlu, 1929; and Kömürcüoğlu, 1950. However, as Bertram states, "no one would or could suggest that these houses should stand in the way of the progress represented by Ankara as the new capital of the new republic. Instead, [they] are represented ... as icons to be celebrated as museums." See: Bertram, 2008, p.93. This approach was supported by the 1925 regulation numbered 583 to form a new city and leave the old city as it was, which influenced the further plans for the growth of the city. See: Bademli, 1985, p.11.

12 Another similar operation was undertaken after the fire in 1929. The burnt areas at the Tahtakale neighborhood in the southern part of Taşhan Square were re-planned with the construction of the new Posta (Şehit Teğmen Kalmaz) Street, and the reorganization of the area from the Municipality building to Posta Street. See: Tunçer, 2011, pp.45-46. 
usually semi-detached and/or attached houses (Figure 3A), and apartments (Figure 3B). The constructions developed further north, and many new houses and apartment constructions took place in the İsmet Paşa and Atıf Bey neighborhoods on Telgraf, Bent, Bostacilar, Ulucak, and Bentderesi Streets, and in the Hacibayram neighborhood on Hacı Bayram, Gaziantep (Gülbaba) and Çamlıca (Yayık) Streets (Table I; Figure 1A and 1B) (Figure 4). Some of the houses of significant figures of the period, such as one of the politician and deputy of the first decade İzzet Ulvi Aykurt, were built in this area (Figure

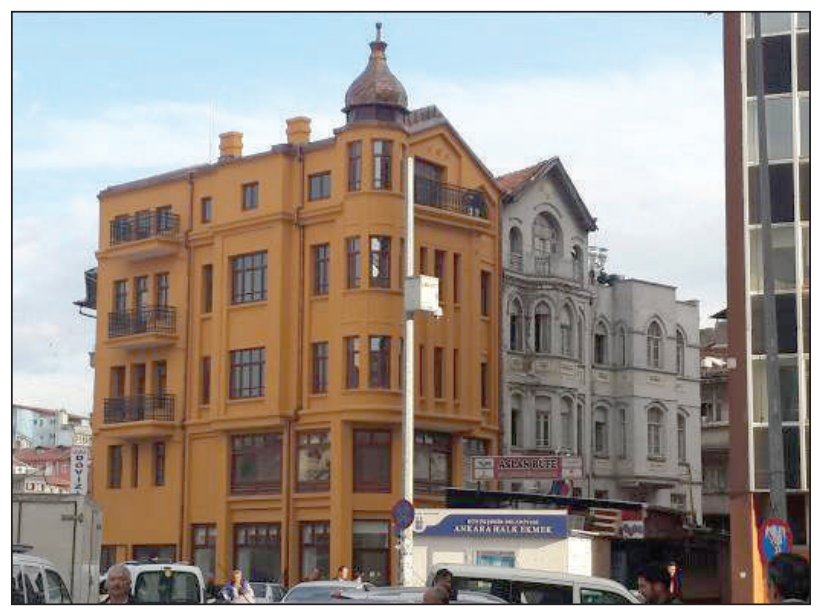

Figure 2A. Erzurum Hotel (Alsancak Street, No: 15), Avrupa Hotel (Susam Street, No: 8) and its addition (Susam and Tahtakale Streets). View from Hal Square. Date: 1916/1917-1920s.

Photograph by: D. Avc1 Hosanl, 2015.

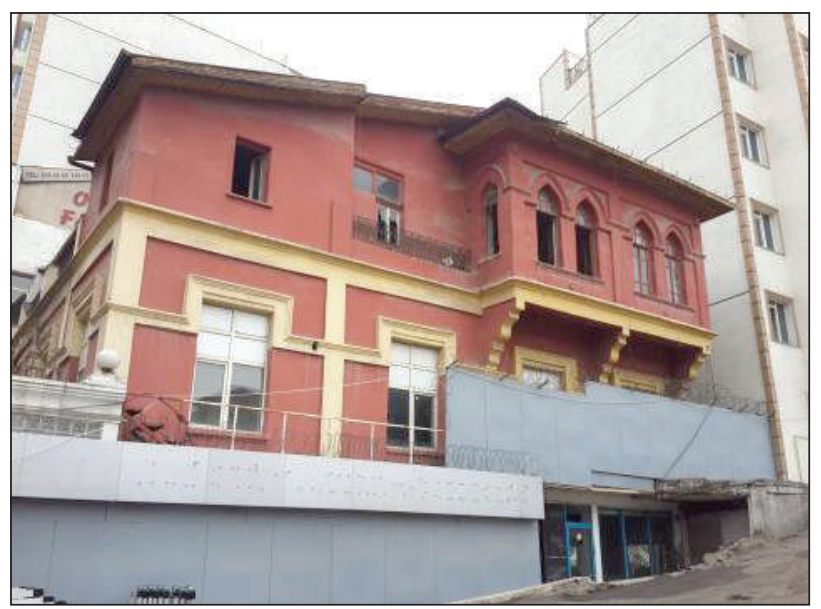

Figure 3A. A house (Çankırı and Armutlu Streets, Karaoğlan Quarter). Date: 1920s.

Photograph by: D. Avc1 Hosanl, 2018.
4A) (Yavuz, A., 2001, pp.289-327), as well as the housing examples known to be produced by the Hungarian craftsmen (Figure 4B and 4C). Being located towards the periphery of the old city, the houses in these regions were usually detached single houses (Figure 4A and 4B), and only a few semi-detacheds or attached houses could be seen here (Figure 4C).

Despite the construction of new houses and apartments that began to transform the traditional neighborhoods in the old city, these proved to be insufficient to meet the housing requirements of the growing population.

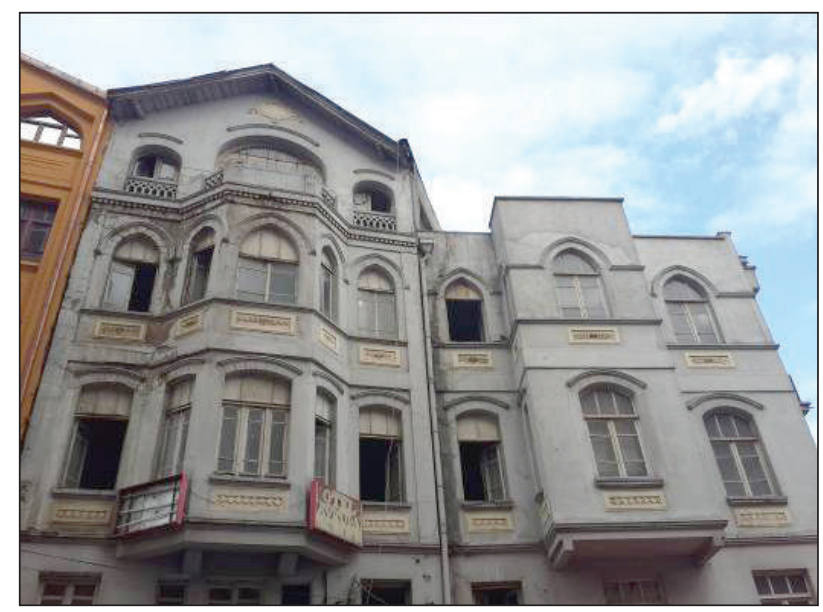

Figure 2B. Avrupa Hotel and its addition. Date: 1916/19171920s.

Photograph by: D. Avc1 Hosanl1, 2015.

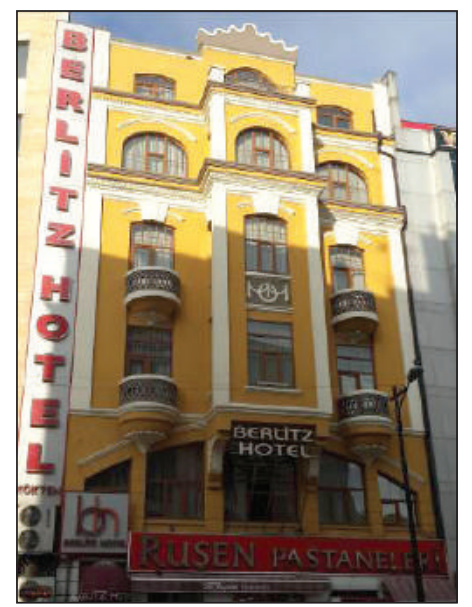

Figure 3B. An apartment (Hükümet Street, No: 4). Date: 1920s. Photograph by: D. Avc1 Hosanl1, 2015. 


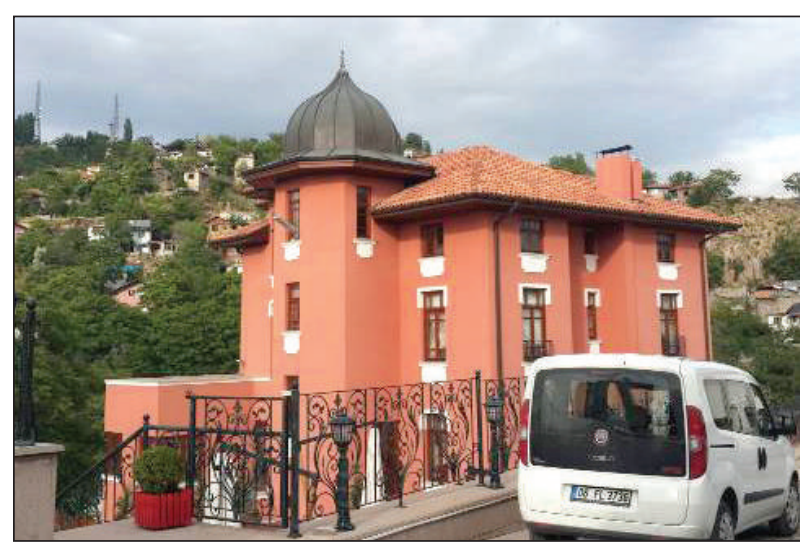

Figure 4A. İzzet Ulvi Aykurt house (Hacı Bayram Veli Quarter). Built by Hungarian craftsmen. Date: 1924-1931. Photograph by: D. Avcı Hosanl, 2015.

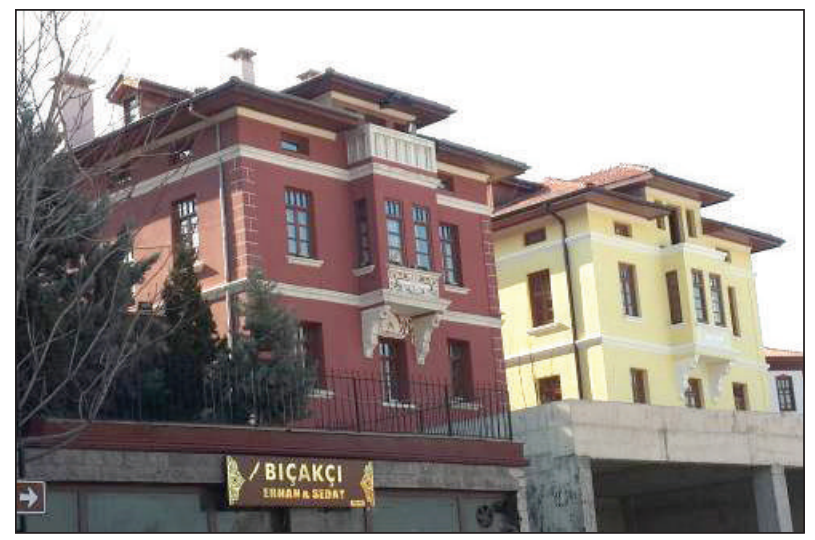

Figure 4B. Twin Hungarian houses (Gaziantep (Çamlıca) Street, Hacibayram Quarter). Date: 1920s.

Photograph by: D. Avcı Hosanlı, 2018.

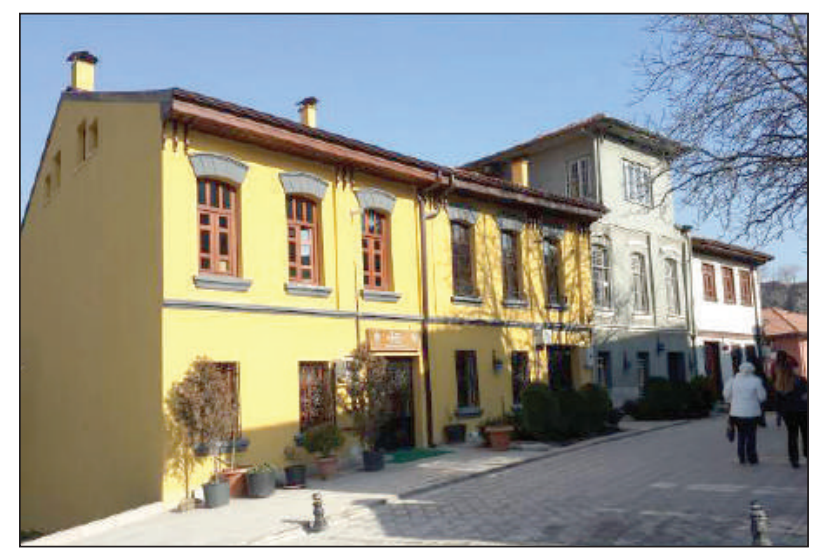

Figure 4C. Three Hungarian houses (Yaylk (Gülbaba) Street, Hacıbayram Quarter). Date: 1920s.

Photograph by: D. Avc1 Hosanl, 2018.
Eventually, the empty areas in and around the historic city were expropriated for new constructions, creating new areas within the traditional context in the Anafartalar, Samanpazarı, Hamamönü, Gündoğdu, İstiklal and the Youth Park quarters (Table I; Figure 1A and 1B). This created a faster transformation of the old city in the areas in the south and west of the citadel towards the Train Station.

During the first years of the Republic, one of the most central areas of Ankara was the Anafartalar quarter (Table I; Figure 1A and 1B) where many new houses and apartments were constructed. Anafartalar Street, established as the main artery of the old city after the Map of 1924, formed its central axis, connecting the Taşhan Square to Samanpazarı, an important commercial and residential center that replaced the Long Bazaar (Uzun Çarşı) of the earlier centuries. During 1920s, Anafartalar Street was divided into three parts. The beginning of Anafartalar Street, from the corner of Hisar Street to Çıkrıkçılar Slope, was defined as the KaraoğlanBalıkpazarı axis and called Balıkpazarı Street. The second part of Anafartalar Street started with its intersection with Posta Street and continued to the intersection of Denizciler (also known as Bahriyeliler) Street. This part was called Yeğenbey Street, as being on the northeast of the Yeğenbey neighborhood. The third part of the street started from its intersection with Denizciler Street and continued to the Samanpazarı quarter, including the Courthouse and the Children's Protection Agency as important public buildings. This part was called Çocuk Sarayı (Children's Palace) Street. As Anafartalar Street became an important artery, new houses and apartments were built here, turning it into a significantly transformed part of the old city following the Karaoğlan quarter.

Balıkpazarı Street was the richer part of the old city, where many shops and restaurants were opened in the ground floors of the new apartments while upper floors were used for residential purposes. The constructions on the Hisarönü side of Balıkpazarı Street were completely finished before 1927 (Dinçer, 2014, p. 44). Hisar Street, leading to the citadel, also developed as a luxurious entertainment street with many restaurants and coffeehouses (Aydın et al., 2005, p. 408). Next, to a number of single houses built there, two or three-storey apartments of the period can also be seen, such as the apartment known as the Büyük (Koç) Apartment (Figure 5). Constructed in the newly developing commercial heart 
of the old city where available land for construction was limited, the houses and apartments built on Anafartalar Street were usually attached with few semi-detached exceptions at the street corners (Figure 9A, 9B; 10A, 10B; $11 \mathrm{~A}, 11 \mathrm{~B} ; 12 \mathrm{~A}$ and 12B).

The areas that became available after fires provided the opportunity for new constructions in the dense area of the old city. One such area of great significance was the Hisarönü neighborhood (also known as Işıklar), which witnessed the 1916 Fire and was re-planned during

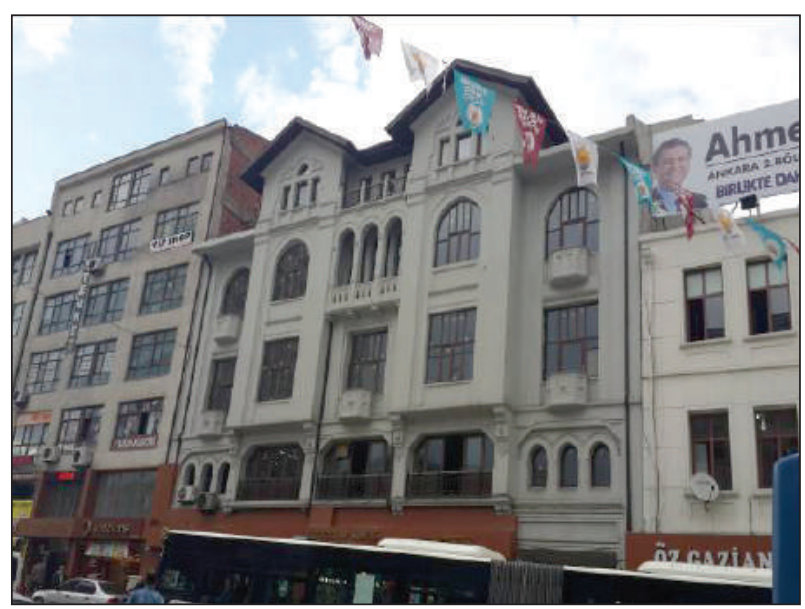

Figure 5. Büyük Apartment (later known as Koç Apartment) (Hisar Street). Date: 1920s.

Photograph by: D. Avc1 Hosanl, 2015.

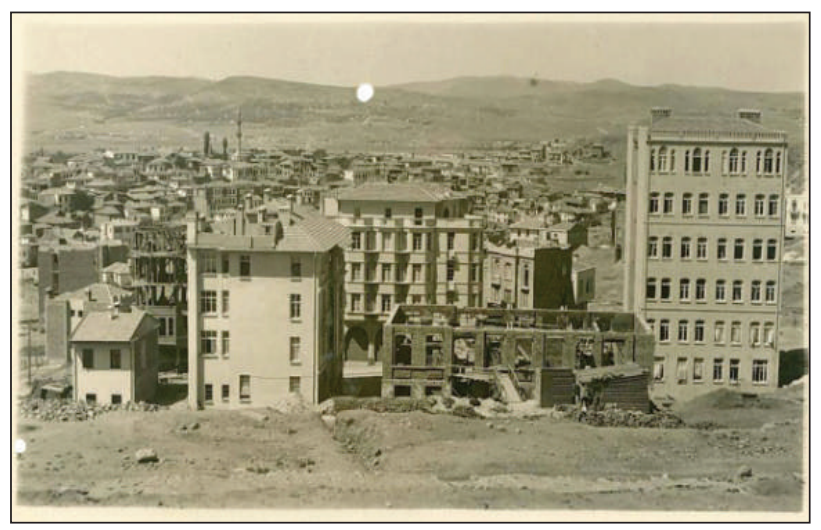

Figure 6A. The Hisarönü Quarter, $1930 .{ }^{13}$ In the middle and at the right: Apartments (Işıklar Street, No: 27 and 22). Source: VEKAM Library and Archive, Inventory no: 1284. the early Republican years (Esin and Etöz, 2015). From Işıklar Street that intersects with Balıkpazarı Street, the fire area could be reached. The new blocks in this area form a large triangular settlement between Anafartalar Street, Çıkrıç̧ılar Slope, İpek and Hisar (Hisarparkı) Streets. Işıklar Street and Konya Street (parallel to Anafartalar Street and Çıkrıkçılar Slope and vertical to Işıklar Street) are the two main streets of the area where many single houses and apartments were built, showing variety in type according to their locations. For instance, towards the empty burnt areas at the skirts of the citadel, in more available spaces, they can be detached; however, towards Anafartalar Street and around Işıklar Street, they were semi-detached if on street corners or attached to the surrounding buildings (Figure 6A, 6B; 7A, 7B; 8A, 8B; 9A, 9B; 10A, 10B; 11A, $11 \mathrm{~B}$ and $12 \mathrm{~A}, 12 \mathrm{~B})$. One of the significant apartments of the period was constructed on Işıklar Street, known as the Erzurumlu Nafiz Bey Apartment designed by Koyunoğlu (Kuruyazıc1, 2008, p.45), and another was built across the street (Işıklar Street No: 22) (Figure 6A, 6B and 7A, 7B). In the Hisarönü neighborhood, many single houses of the period also existed among apartments on Hekimler, Konya, Mevsim, Firuzağa, Nilüfer, Alataş, and Karakuş Streets and towards the Çıkrıkçlar Slope (Figure 8A and $8 \mathrm{~B})$. One of the other significant apartments of the period was constructed on Mevsim Street, connecting Konya and Anafartalar Streets (Figure 9A). Another known apartment within the area on Hekimler Street, vertical to

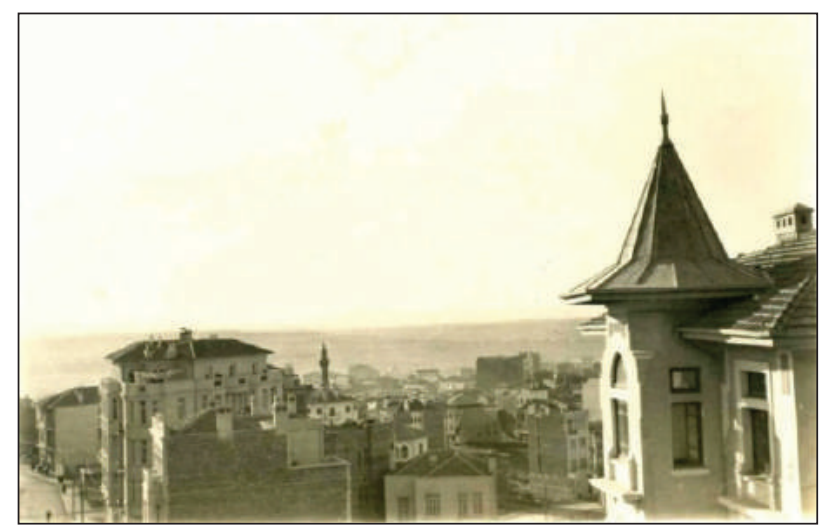

Figure 6B. Houses and Apartments (Hisarönü Quarter). Işıklar Street, 1925 (Left back: Erzurumlu Nafiz Bey Apartment). Source: VEKAM Library and Archive, Inventory no: 2140.

13 Even though the date is noted as 1930 at the VEKAM Archive, the postcard should have actually been taken before 1927 as the apartment seen on the left is under construction, and it is known from other postcards that the apartment was finished before 1928. 
Anafartalar, and parallel to Hisar Streets, was the Hatay Apartment, also known as the Hasan Pehlivanlı OfficeBuilding (İş Hanı), initiated by Hasan Fehmi Ataç (Figure 7C) (Aslanoğlu, 2010, p.267).

The Karaoğlan-Balıkpazarı axis diverges into the Yeğenbey Street from the Posta Street and continues from there until Denizciler Street. On both sides of the street, mostly apartments, as well as some single houses, were built during the 1920s (Figure 10A and 10B) by private initiatives on available empty lots within the already crowded Anafartalar Street of the old city, and almost all were thus small and narrow, adjacent to or semi-detached from neighboring buildings. They were at most three to five storeys high with ground floors used as shops, such as the towered-apartments of the Yeğenbey (Anafartalar) Street (Figure 11A and 11B). On this street,

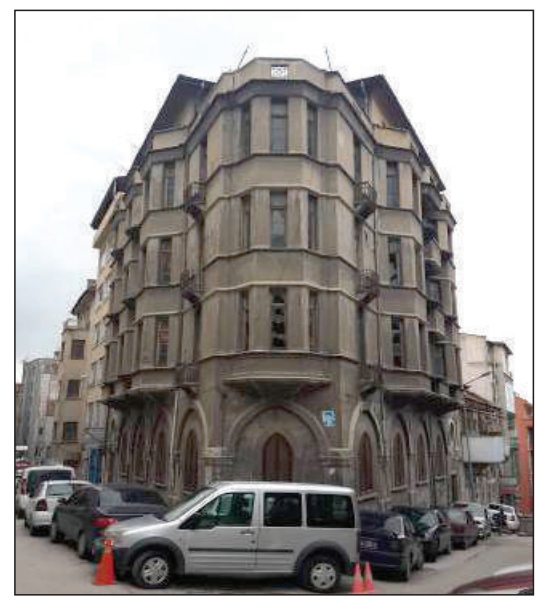

Figure 7A. Erzurumlu Nafiz Bey Apartment (Işıklar Street, No: 27). Date: 1922.

Photograph by: D. Avc1 Hosanl, 2015.

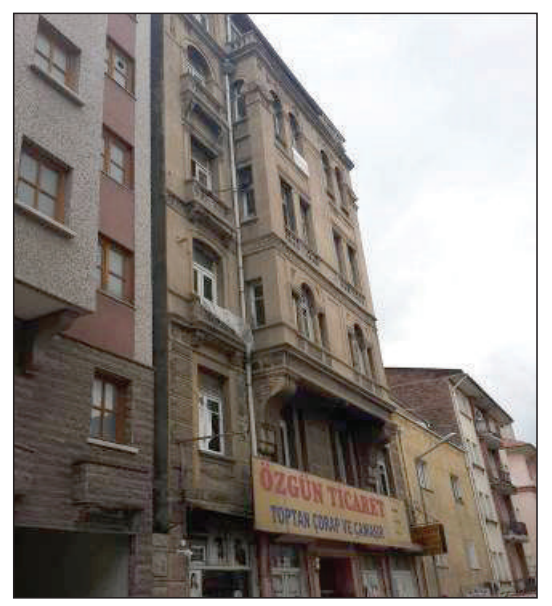

Figure 7B. An apartment (Işıklar Street, No: 22). Date: before 1927. Photograph by: D. Avc1 Hosanl, 2015.

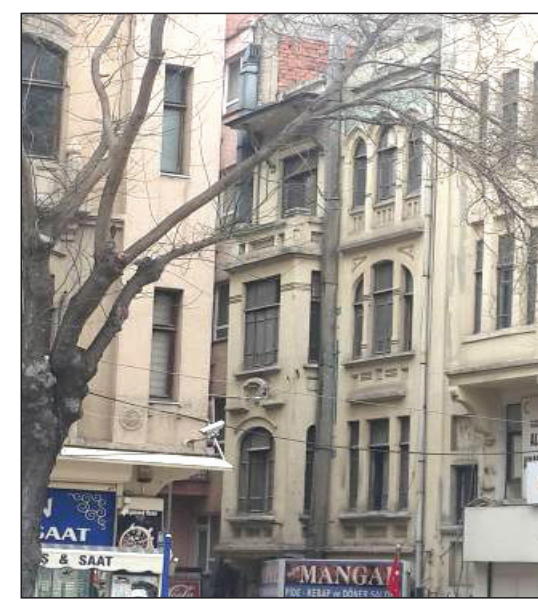

Figure 7C. Hatay Apartment (Hasan Pehlivanlı İşhanı) (Hekimler Street, No: 4). Date: before 1927.

Photograph by: D. Avc1 Hosanlı, 2017.

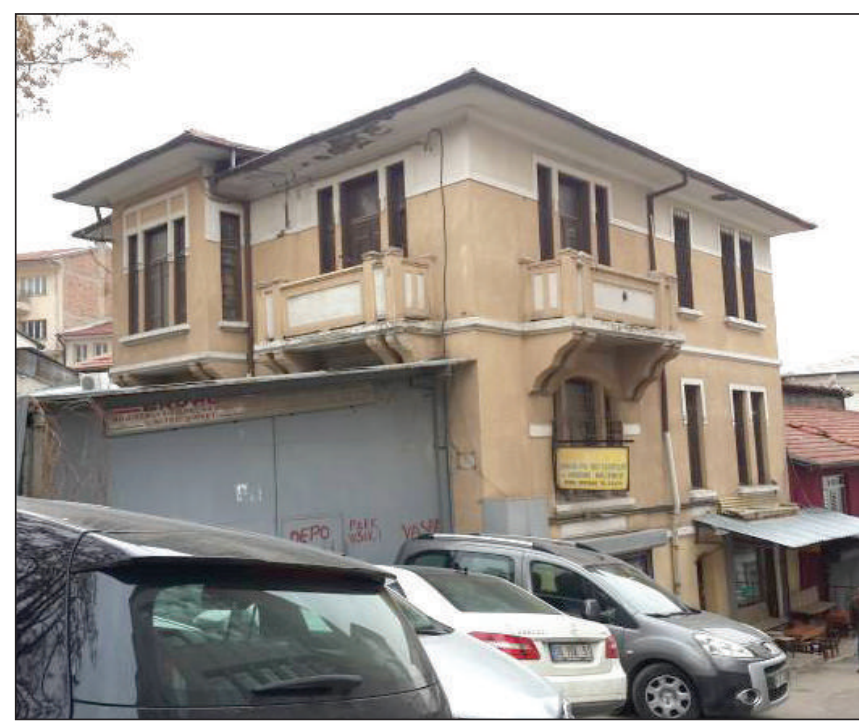

Figure 8A. A single houses (Konya-Kahraman Street, Hisarönü Quarter). Date: 1920s.

Photograph by: D. Avc1 Hosanlı, 2018.

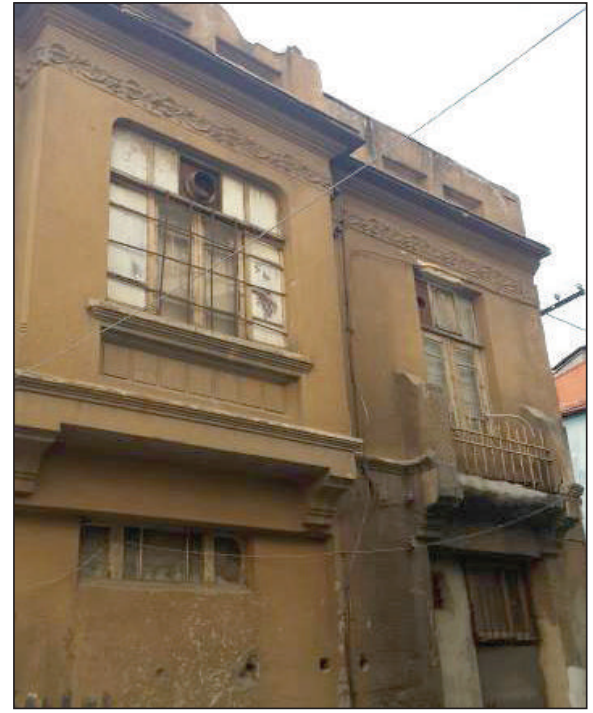

Figure 8B. A single house (Kocalar Street, No: 1, Hisarönü Quarter). Date: 1920s.

Photograph by: D. Avc1 Hosanl, 2015. 
other distinguished apartments of the period were also located, including the Sakarya Apartment initiated by Nuri Conker, member of parliament (Aydın et al., 2005, p. 462) (Figure 9B).

On Çocuk Sarayı Street, next to the Children's Protection Agency (Himaye-i Eftal: Çocuk Esirgeme Kurumu), the institution's tenement apartment was built as one of the apartment complexes that are authentic to Ulus (Figure 12A). These are large apartments that housed many flats, constituted different facilities and formed small communities within themselves. One of the other well known apartments of the period, the Hasan Fehmi Ataç Apartment (later known as the Büyük Hotel) initiated

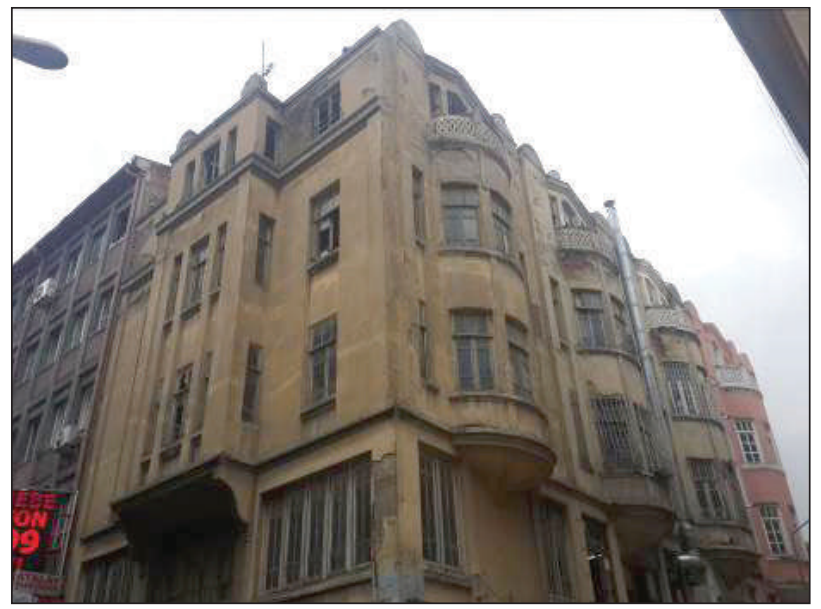

Figure 9A. An apartment (Mevsim Street, No: 6, 8, 8a). Date: 1924.

Photograph by: D. Avc1 Hosanl, 2015.

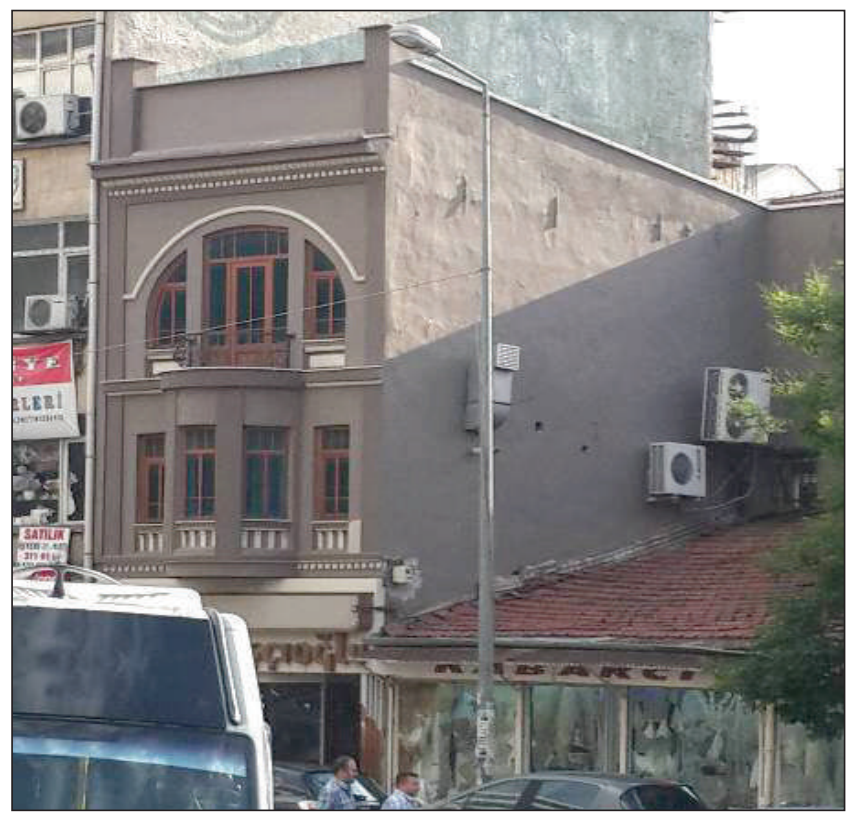

Figure 10A. A single house (Yeğenbey (Anafartalar) Street, No: 36). Date: 1920s.

Photograph by: D. Avc1 Hosanl, 2015.

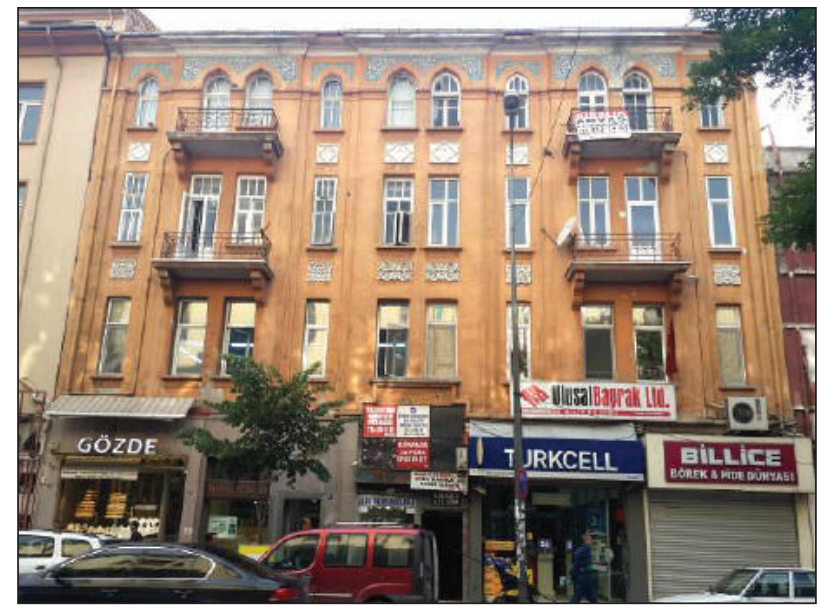

Figure 9B. Sakarya Apartment (Anafartalar Street). Initiated by Nuri Conker. Date: 1923.

Photograph by: D. Avc1 Hosanl, 2015.

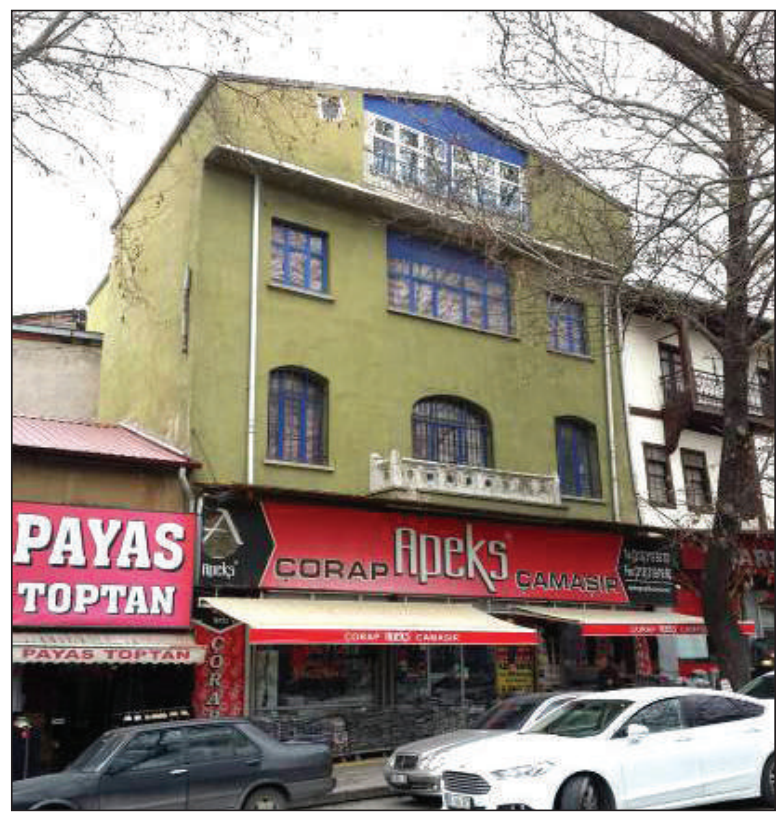

Figure 10B. A single house (Çocuk Sarayı (Anafartalar) Street, No: 89). Date: 1920s.

Photograph by: D. Avc1 Hosanlı, 2018. 
D. Avcı Hosanlı ve T.E. Altan, The Residential Architecture of Ankara during the 1920s: The Housing Types

by Minister of Finance Hasan Fehmi Ataç (Aslanoğlu, 2010, pp. 271-273), is at the intersection of Yeğenbey (Anafartalar) - Çocuk Sarayı Streets with Denizciler Street (Figure 12B), and is one of the large and extravagant apartments of the decade in the old city. The road dividing the traditional neighborhoods from these new blocks is Acıçeşme Street, leading to the historic Şengül
Bath (sixteenth century). The new apartments and houses of the 1920s were also constructed in the new blocks here (Figure 13A and 13B).

The southeast part of the city, including the Samanpazarı, Hamamönü, and Gündoğdu (also known as the Dumlupinar) quarters, was also affected by the transfor-

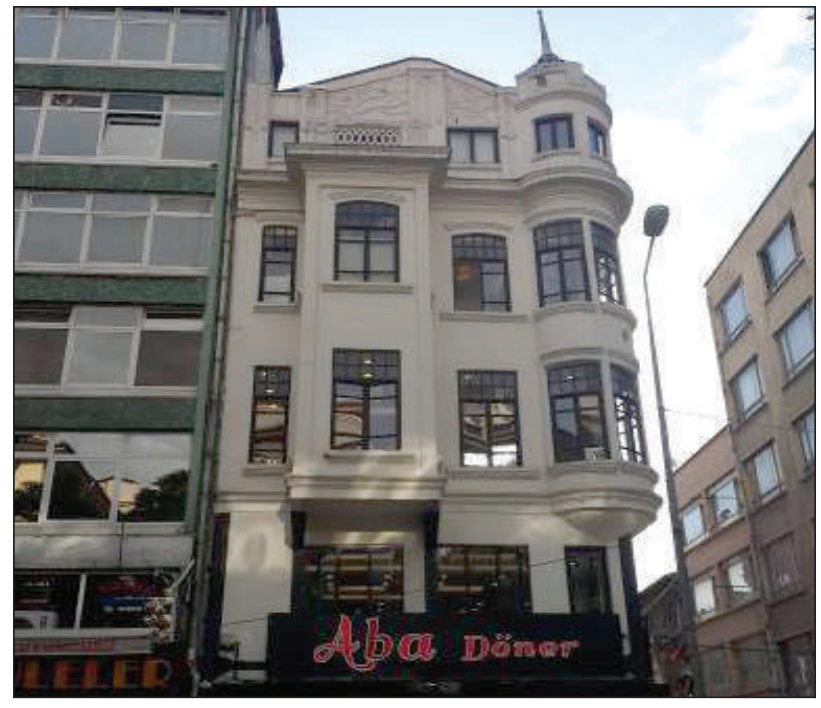

Figure 11A. An apartment (Anafartalar Street, No: 42). Date: before 1928

Photograph by: D. Avc1 Hosanl1, 2015.

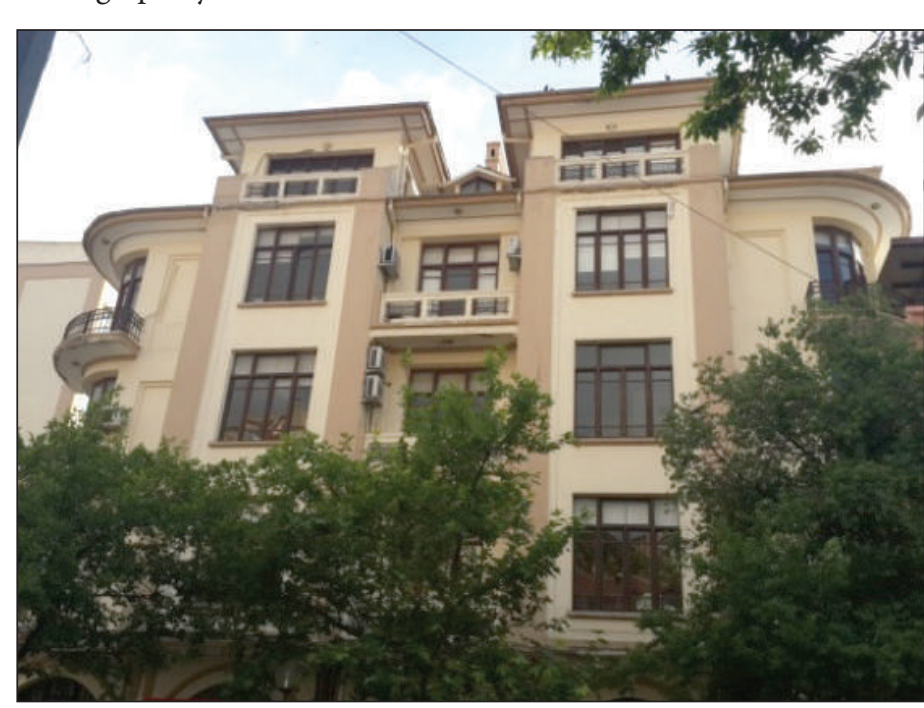

Figure 12A. Children's Protection Agency and its rental apartment (Çocuk Sarayı (Anafartalar) Street). Architect: Arif Hikmet Koyunoğlu. Date: 1926. Photograph by: D. Avc1 Hosanlı, 2018.

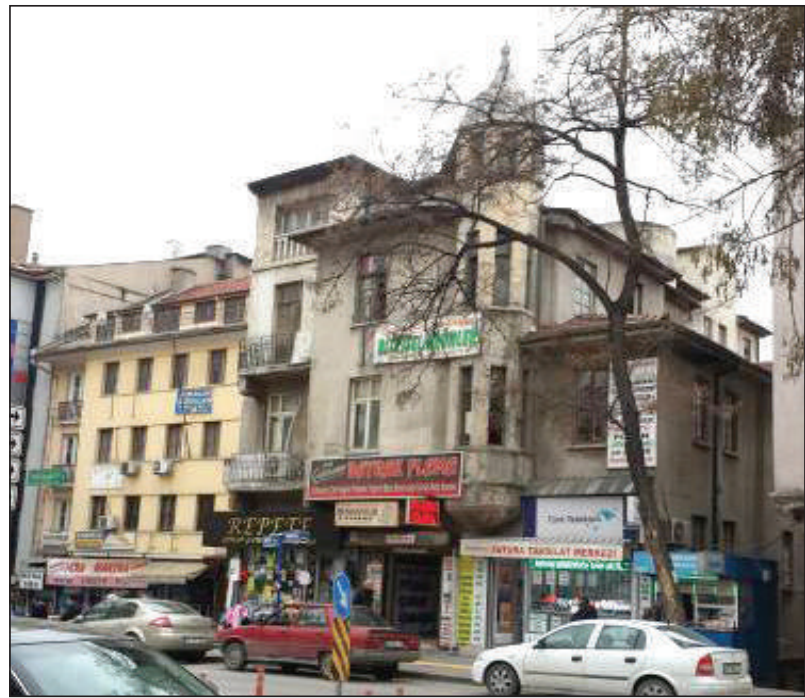

Figure 11B. An apartment (Anafartalar Street, No: 60). Date: before 1928.

Photograph by: D. Avc1 Hosanl, 2018.

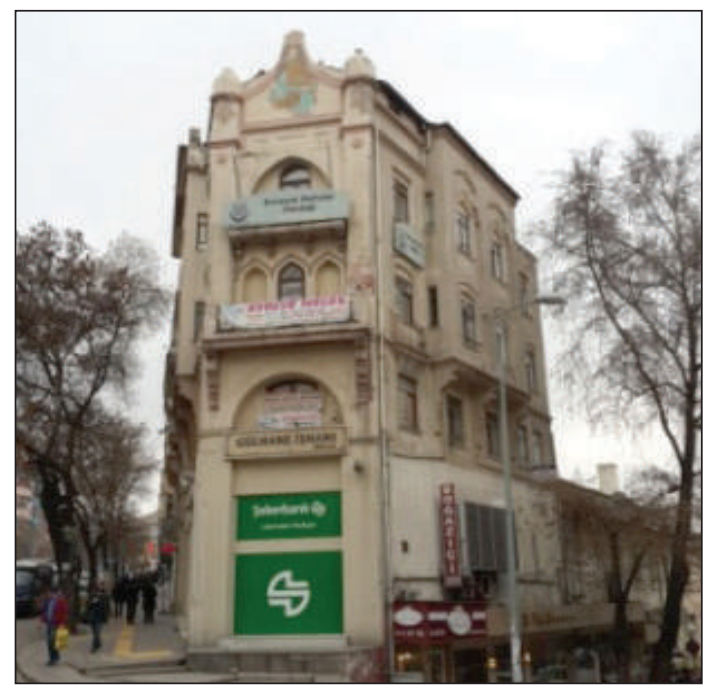

Figure 12B. Hasan Fehmi Ataç apartment (Çocuk Sarayı (Anafartalar) Street). Date: 1925. Photograph by: D. Avc1 Hosanlı, 2018. 
mation of the city during the decade although it mostly preserved its traditional residential neighborhoods (Table I; Figure 1A and 1B). The Hamamönü quarter, one of the oldest settlements of Ankara that was named after the Karacabey Bath (1430s) (Poyraz and Gündoğan, 2014, p. 71), was the most densely populated traditional residential area of the old city after the Inner Castle (Öztürk, 2007, p.89; Poyraz and Gündoğan, 2014, p.71). The establishment of the Republic introduced many social changes to the area as it housed families of different classes with the changes in the city's social, financial, and spatial characteristics (Poyraz and Gündoğan, 2014, p.71). The newcomers to the city, with regardless of their social status, stayed at least for a while in or around the area due to the lack of enough accommodation in the other parts of the old city. Apart from temporary accommodation, the area also provided permanent settlement to the newcomers with lower incomes who could not afford to stay in hotels such as Taşhan, and instead looked for rental rooms in traditional houses (Şenyapılı, 2004; Poyraz and Gündoğan, 2014, p. 75). New blocks also appeared in this part of the old city in the Gündoğdu quarter, towards the railroad, to the east of the Hamamönü quarter, at the south of Talatpaşa Boulevard. There used to be a ceme-

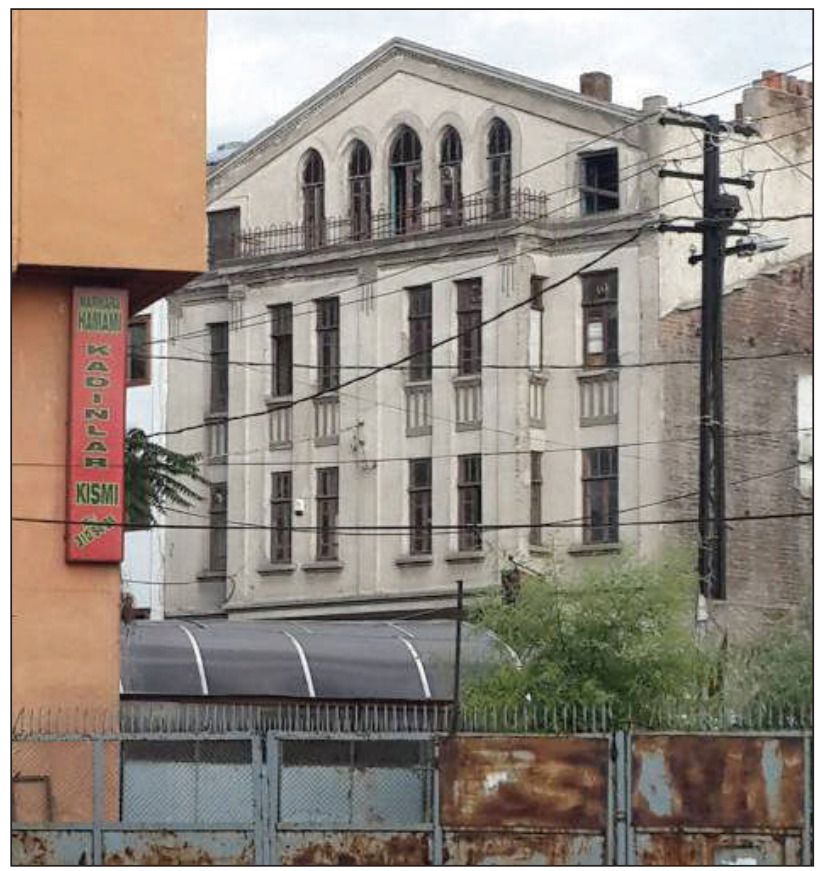

Figure 13A. An apartment (Acıçeşme Street). Date: 1920s. Photograph by: D. Avc1 Hosanl, 2015. tery here, and the area became part of the expropriated lands for construction in the 1920s. Two-storied, modest, and simple, single-family houses in gardens, designed as state-officer lodgings, were constructed in this neighborhood (Şenyapıll, 2004; Poyraz and Gündoğan, 2014, p.77). Five houses, also known as the Hamamönü Foundation (Evkaf/Vakıf) Houses, designed by Giulio Mongeri, were constructed in this quarter (Figure 14A and 14B). Apart from those, private housing projects also took place in the area (Figure 15A and 15B).

As the area of the city was expanding with construction along the central axis starting from the Taşhan Square and leading towards the south, along with the new public buildings and places, new houses and apartments began to take place also in this part of Ankara that included the İstiklal and Youth Park quarters and the new blocks towards the Train Station (Table I, Figure 1A and 1B). Among the public buildings lined along Banks Street (later part of Atatürk Boulevard), only the Directory of State Monopoly (Tekel) included a residential function with its lodgings designed together with the offices in the building (Figure 16A). The real spread of the old city was witnessed by the constructions towards the Train Station.

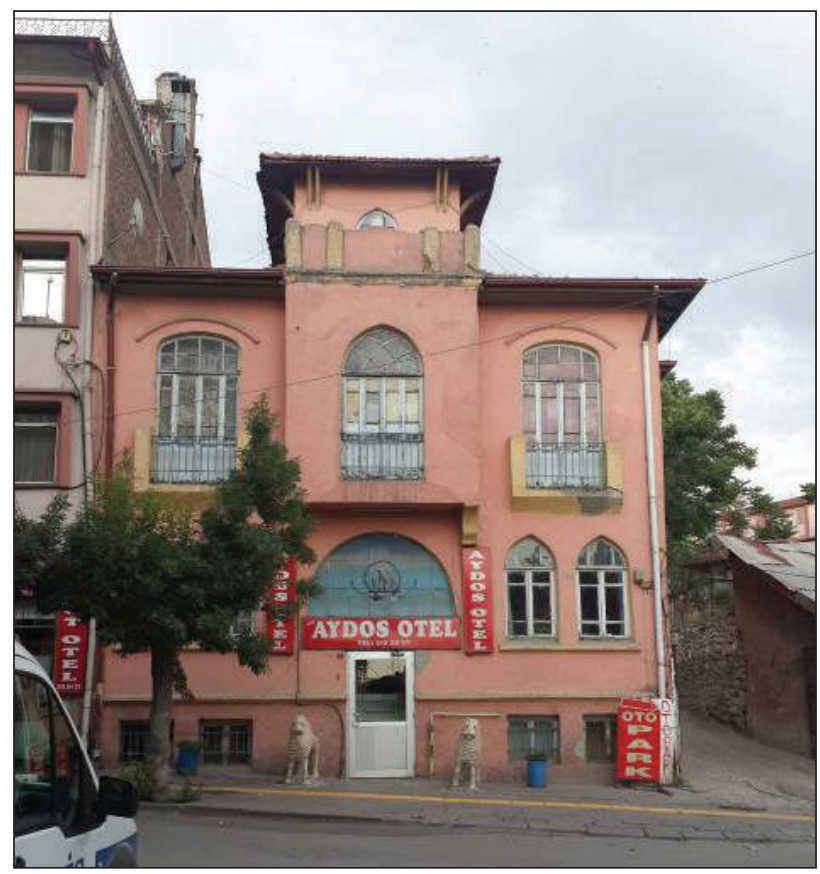

Figure 13B. A house (Denizciler Street, No: 13). Date: 1920s. Photograph by: D. Avc1 Hosanl, 2015. 
D. Avcı Hosanlı ve T.E. Altan, The Residential Architecture of Ankara during the 1920s: The Housing Types
in the Settlement Zones of the New Capital City

New blocks were formed in the new construction areas provided from drying the swamps among Banks Street, Talatpaşa Boulevard and Station Square (Tunçer, 2014, pp. 32-33). Both sides of Station Street were reorganized for new constructions. At the area among Station, İstiklal and Banks Streets, and at the north of the Youth Park, a new triangular block was formed as proposed by Lörcher where the Foundation Apartments designed by
Kemalettin Bey and the Foundation Houses designed by Kemalettin Bey and Koyunoğlu were built (Figure 17A and 17B) close to the new Ankara Palas Hotel (Vedat Tek and Kemalettin Bey, 1924-1928) (Yavuz, 2000, pp.233252). The Foundation Houses became the prototypes of single detached garden houses to be constructed in the newly developed parts of the city, and the Foundation Apartments were the significant examples of the

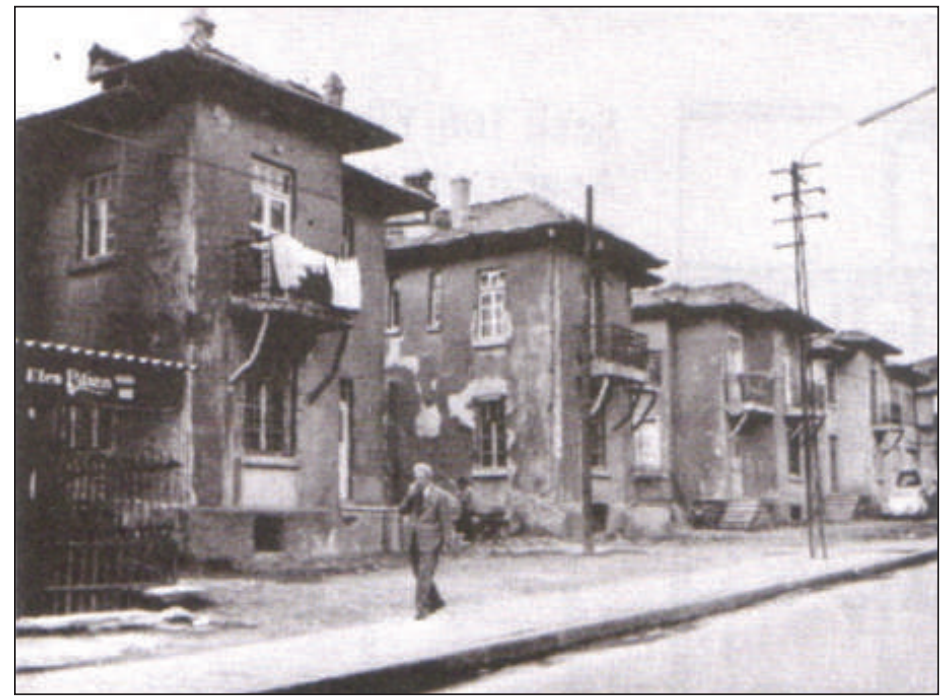

Figure 14A. Hamamönü Foundation Houses, the 1920s. Architect: Giulio Mongeri. Date: 1924-1925. Source: Aslanoğlu, 1980, s. 378.

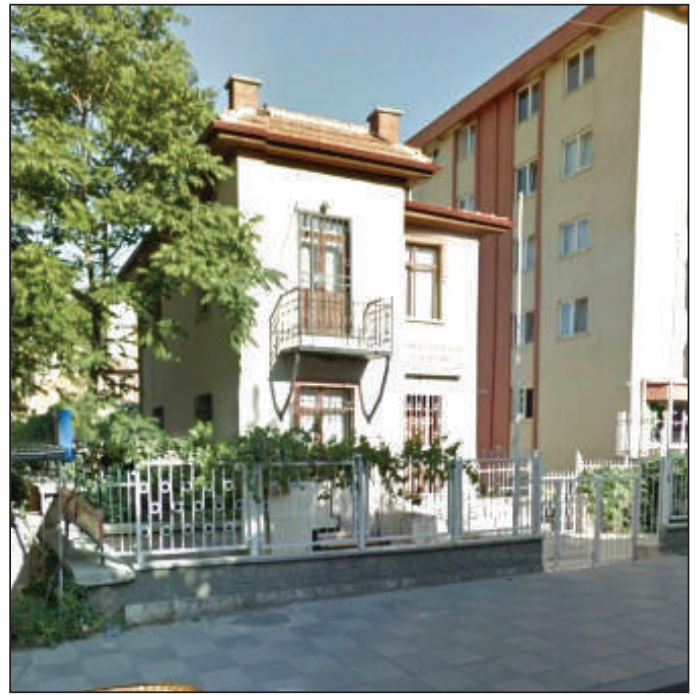

Figure 14B. One of the Hamamönü Foundation houses that still stands today (Dumlupinar Street, No: 13). Source: Google Earth, 2016.

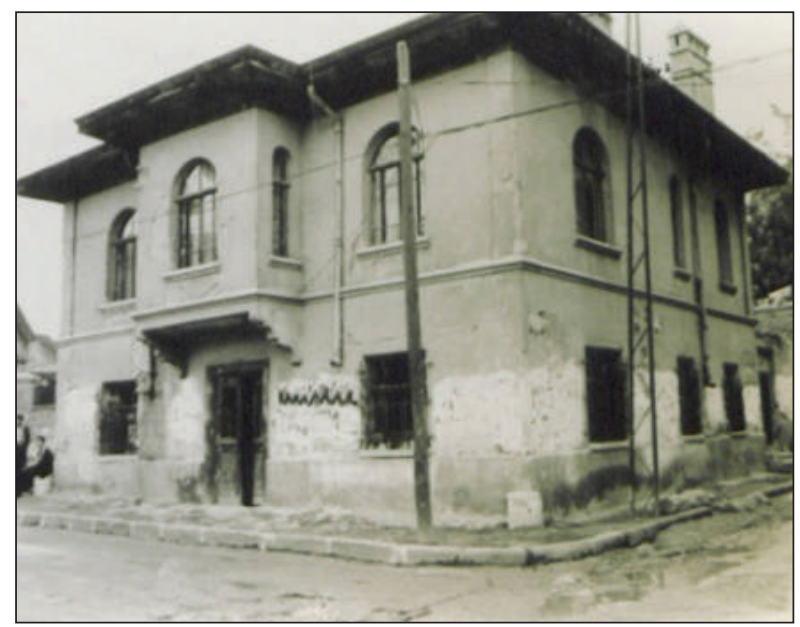

Figure 15A. A house (Gündoğdu Street, No: 1), Date: 1920s. Source: VEKAM Library and Archive, Inventory no: TKV0107.

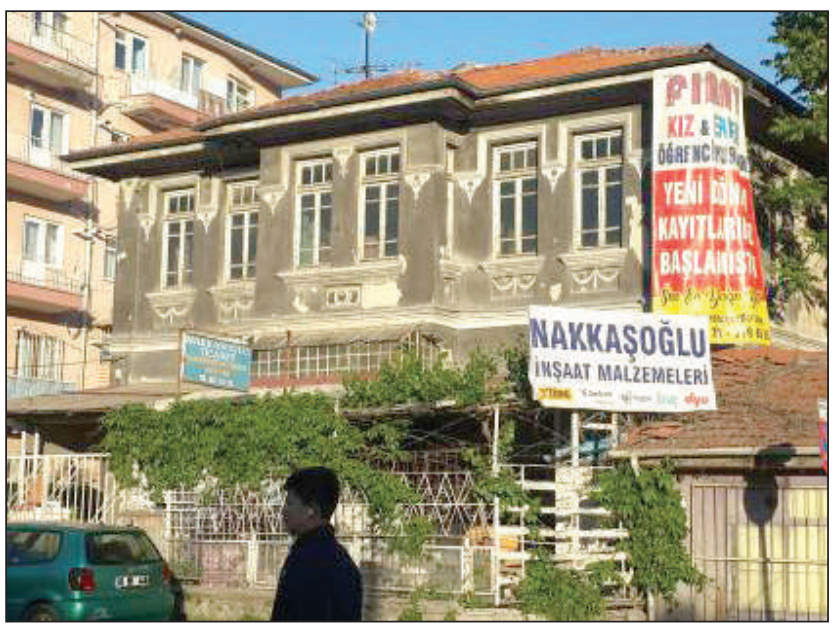

Figure 15B. A house (Dumlupinar Street No: 8. Date: 1920s. Photograph by: D. Avc1 Hosanl, 2018. 
apartment-complexes peculiar to the old city at the time. Another example for apartment-complexes is the Lodgings of the State Railways (Devlet Demiryollar Idare-i Umumiyesi) designed by Kemalettin Bey and built next to the Train Station (Figure 16B).

\section{The Transformation of the Vineyards}

The housing need after Ankara had been declared as the capital city affected the transformation of not only the old city but also the traditional vineyards in its peripheries (Table I). The vineyard houses had been used for centuries, and as Vehbi Koç describes:

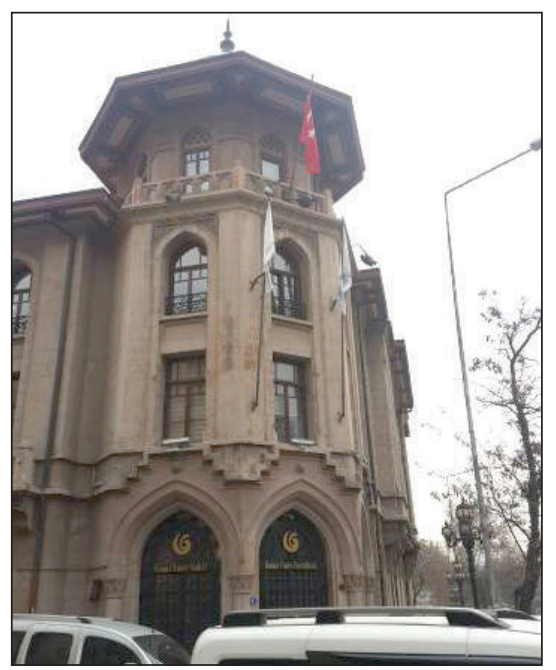

Figure 16A. Building and Lodgings of Directory of State Monopoly (Tekel). Architect: Giulio Mongeri. Date: 1928. Photograph by: D. Avc1 Hosanl1, 2018,

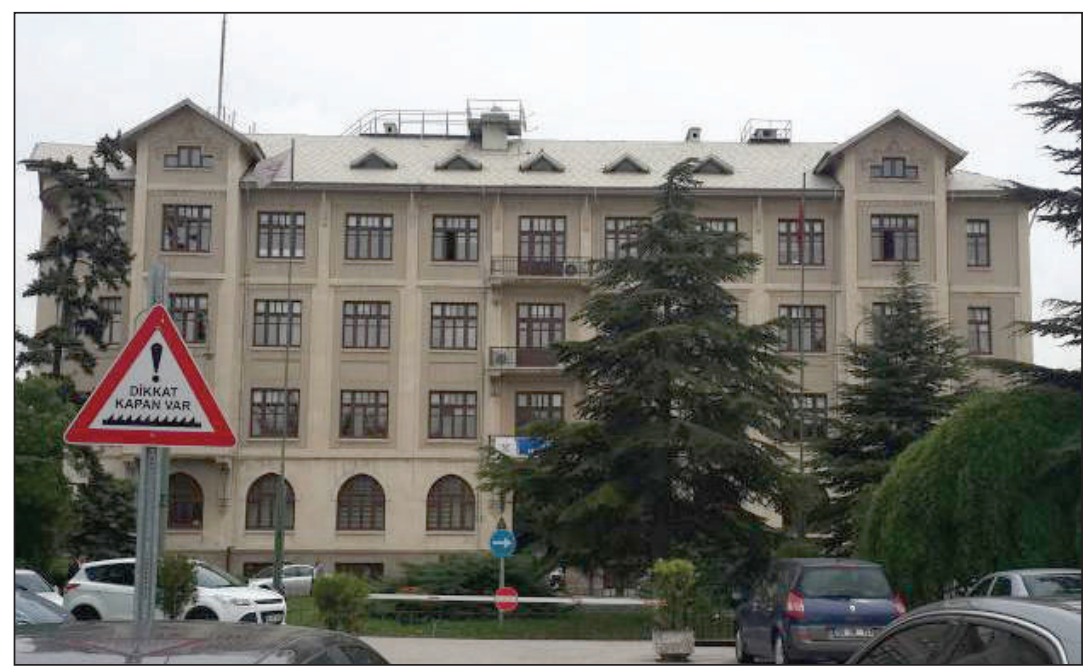

Figure 16B. Building and Lodgings of State Railways Administration. Architect: A. Kemalettin Bey. Date: 1925-1928. Photograph by: D. Avc1 Hosanl, 2015.

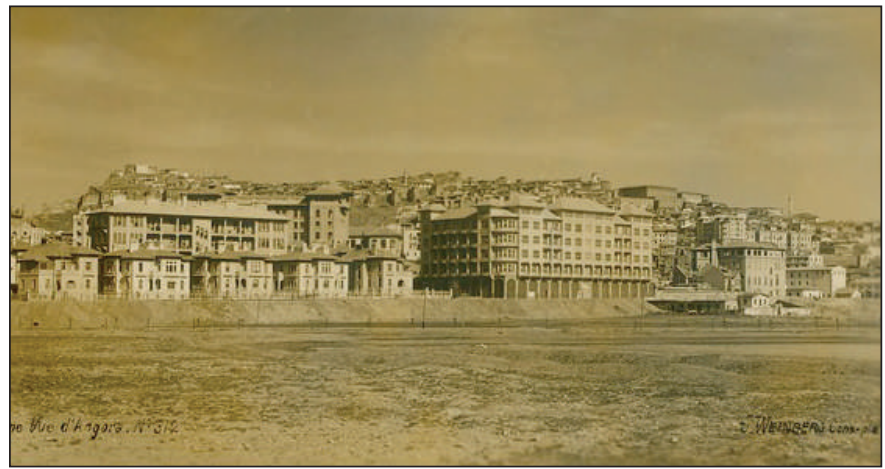

Figure 17A. Foundation Houses, 1928.

Architects: A. Kemalettin Bey and Arif Hikmet Koyunoğlu, Date: 1923-1924.

First Foundation Apartment (Belvü Palas), Architect: A. Kemalettin Bey, Date: 1926-1930.

Second Foundation Apartment, Architect: A. Kemalettin Bey, Date: 1926-1928/1930.

Source: VEKAM Library and Archive, Inventory no: 1007.

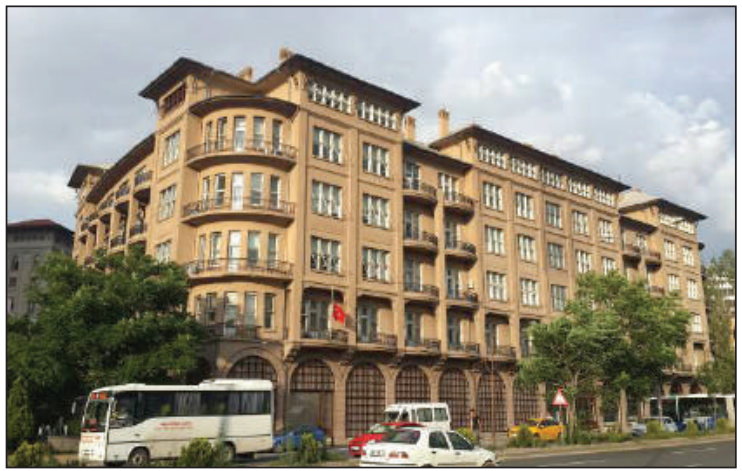

Figure 17B. Second Foundation Apartment (İstiklal Street). Architect: A. Kemalettin Bey. Date: 19261928/1930.

Photograph by: D. Avcı Hosanlı, 2015. 
In Ankara, there was a tradition to move to the summerhouses. Rich and middle classes used to go to vineyards, I do not know whether it was because of malaria (in the city) or for entertainment... We had a vineyard house as well. We used to go to our vineyard in the Çoraklık area below Keçiören.

Like us, in Çoraklık, many were Muslims. A little further, in the Keçiören area, Catholics and Armenians resided. The care of their vineyards, beauty of their buildings and gardens could be seen right away. The rich Christians used to go to summer houses in the Keçiören, Etlik, and Çankaya regions. However, the Jewish dwellers did not have this tradition (Dündar, 2007, p.22 [translation by the authors]).

Aktüre (1987, p.140) dates the prevalent use of the vineyards to the end of the $19^{\text {th }}$ century as the arrival of the railway to Ankara accelerated the use of horsecarriages in and around the city. It is known that many of the state employees who could not find accommodation within the old city, before the construction of the new city, settled in the vineyard houses during the 1920s. Due to limited housing in the old city, traditional vineyard houses were widely preferred in this first decade of the Republic for temporary sheltering and even continuous usage, providing a lifestyle that formed a transition between the urban and the rural landscape with their low-density neighborhoods away from the pressure of land speculation in the city center (Cengizkan, 2002, p.119).

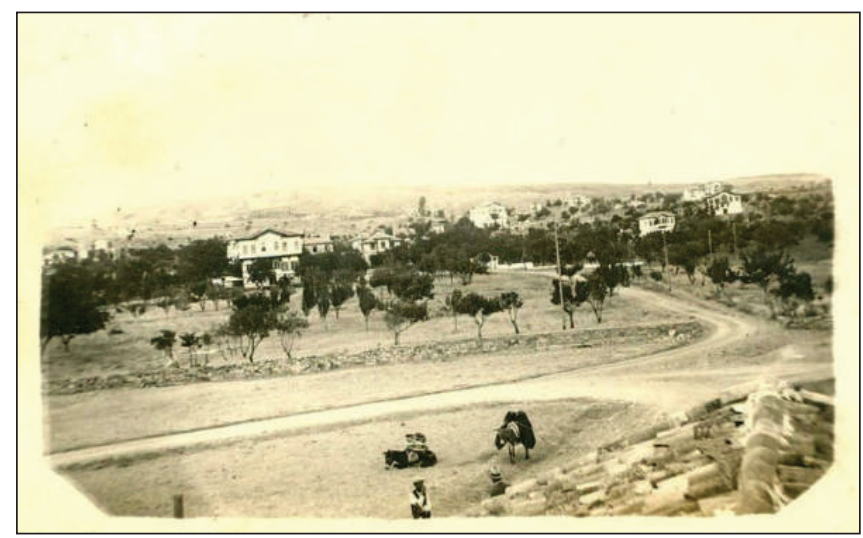

Figure 18A. Vineyard houses (Keçiören).

Source: VEKAM Library and Archive, Inventory no: 2451.
Indeed, the authentic lifestyle continued in the vineyards for a while even after Ankara had become the capital city (Ortayli, 2014, p.113), and the vineyard houses, which had similar characteristics with the traditional houses in the city (Özgönül and Gökçe, 2001, p.277), had to be restored and maintained by their new residents who struggled hard to live in them. Nonetheless, these houses solved the contemporary housing problem to a degree (Figure 18A). After the developments in the 1920s in the other parts of the city, the vineyard houses also started to be altered with the inclusion of technical advancements. Additionally, apart from their residential function, some vineyard houses were also used for public and commercial purposes, such as embassies and offices. Thus, along with the old city, the main vineyard neighborhoods of Keçiören, Etlik, Çankaya, Dikmen, and Esat were also transformed.

Çankaya had been one of the vineyard areas before it was connected to Yenişehir and became the most prestigious area of the capital city as one of the vineyard houses here was transformed into the President's House (Figure 18B). As requested by Mustafa Kemal, a vineyard house was searched for around Kavaklıdere and Çankaya, and the Kasapoğlu mansion that had once belonged to an Armenian merchant named Kasapyan was considered as a suitable choice (Yavuz, 2001, p.342). Falih Rifkı Atay argues that the house was owned by an English wool merchant (Atay, 1969, p.352; Yavuz, Y 2001, p.342); and Yavuz suggests that the house might have used by both merchants in different periods. In 1921, the house was

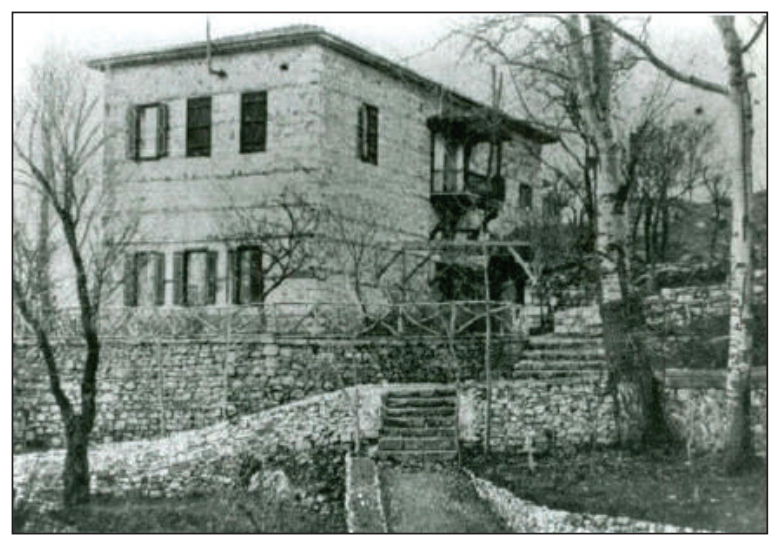

Figure 18B. A Vineyard house (later President's Mansion) (Çankaya).

Source: VEKAM Library and Archive, Inventory no: 0216. 
bought by Hoca Rıfat Börekçi (the Head of Defense of Law Society) for the Ankara Municipality and presented to Mustafa Kemal as a gift (Atay, 1969, p. 352; Batur, 2003, p. 193). It went through an improvement process according to Vedat Tek's project after 1924, which was completed by Koyunoğlu as stated in his memoirs (Kuruyazıc1, 2008), and by the works of some foreign firms throughout the 1920s (Batur, 2003, p.206).

Despite the significant role of the vineyard houses in the early years of the Republic, even hosting the President himself, the families who could improve their financial status, or who were waiting for Yenişehir houses to finish, started gradually to leaving them and moved to the newly developing neighborhoods of Ankara, to the new housings up to contemporary life standards.

\section{The Formation of the New City: Yenişehir}

The efforts continued to transform the old city into an ideal modern capital city during the first decade of the Republic; however, the historic part of the city was insufficient as to meet the housing requirements of the increasing population and it soon became overcrowded. In addition to this, it could not provide an ideal setting for the ideological requirements of modernization of the new state as daily life in the traditional neighborhoods mostly continued as before. As a result, the idea of forming a new city soon started to be considered, and planning efforts were put into practice for a city that would be built from scratch. Accordingly, while the transformation of the old city continued, a new city started to be formed simultaneously, envisioned as a manifestation of the national capital city that was worthy of the new and modern state.

With the realization that the continuous increase in the population would force Ankara to expand beyond the boundaries of the old city, the expansion towards the south of the city, to the empty lands and plantation fields, occurred with the law on the expropriation of lands (Cengizkan, 2004, p.49). It was decided by the government that the new housing and management facilities of the city would be established in this newly developing part of the city called Yenişehir (Cengizkan, 2004, p.70-71). ${ }^{14}$ Then followed the plan prepared for the new city by Lörcher in 1925, which was partially implemented and shaped the further development of the area. This newly developing part of the city, or a completely new city within itself, was planned to include a new parliament building, a quarter of ministries and institutions, and most importantly, a housing neighborhood for state employees and higher social classes (Cengizkan, 2009, p.36). Spacious Yenişehir, as developed based on the "garden city" concept (Benevolo, 1971, pp.348-358; Akcan, 2009, p.41), would also have large public spaces with avenues, public squares, and parks.

In 1926-1927, a new axis was established that connected the old and the new cities, defined as Gazi Mustafa Kemal (later Atatürk) Boulevard, which was planned with its roots in the past, starting at the Taşhan Square in the historic city center, and extending towards the future of the city in the new settlement area through Yenişehir to Çankaya in the further south. The boulevard was designed also as a "green band" with large squares and parks to house cultural activities of Ankara, and with plantation alongside the pedestrian and vehicular streets (Figure 19) (Al, 2011, pp.33-34). Many public buildings and private single houses of the 1920s were built on both sides of the boulevard, starting from the old city towards the new city. In the open land of Yenişehir, available for construction, the residential architecture consisted of garden houses, i.e. single houses, detached from surroundings and located in large gardens and courtyards. The first part of Yenişehir reached as one moved from the old city along the boulevard, started from the Sihhiye Square and continued until the Havuzbaşı (later Kurtuluş and Kızılay) Square, where many single houses were constructed as the first housing examples of Yenişehir (Table I; Figure $1 \mathrm{~A}$ and 1B). The Fevzi Paşa Mansion (Figure 20A), the Mustafa Fahri Bey House (Figure 20B), both designed by Koyunoğlu, are assumed to be among them; however, their exact locations in the area are unknown.

After the Sihhiye Square, passing through the Zafer (Victory) and Millet (Nation) Squares comes the

14 The "big expropriation", as defined by Cengizkan, provided the formation of the Yenişehir, Kurtuluş, Maltepe, and Kavaklıdere/Çankaya regions, with the condition that one fourth of these lands would be available for constructions in line with the Building Law (Ebniye Kanunu), thus providing sufficient income for their previous owners; nevertheless, the plan also provided the unconditional formation of public areas such as the Youth Park, Kurtuluş Park, Industrial Region, Station Region, Hipodrom and the Ministries Quarter. See: Cengizkan: 2004 , p.48. 
D. Avcı Hosanlı ve T.E. Altan, The Residential Architecture of Ankara during the 1920s: The Housing Types
in the Settlement Zones of the New Capital City

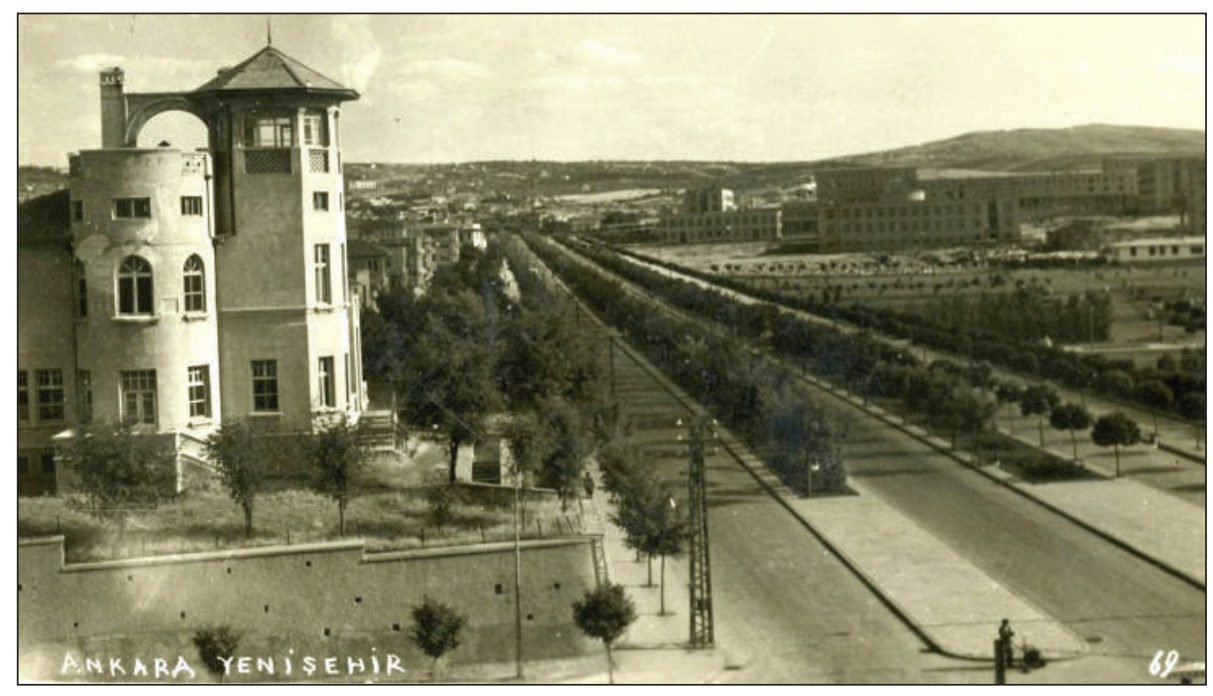

Figure 19. Gazi Mustafa Kemal (Atatürk) Boulevard and Cemil Uybadin Mansion (later Italian Embassy) (Yenişehir).

Date: 1924-1925.

Source: VEKAM Library and Archive, Inventory no: 1516.

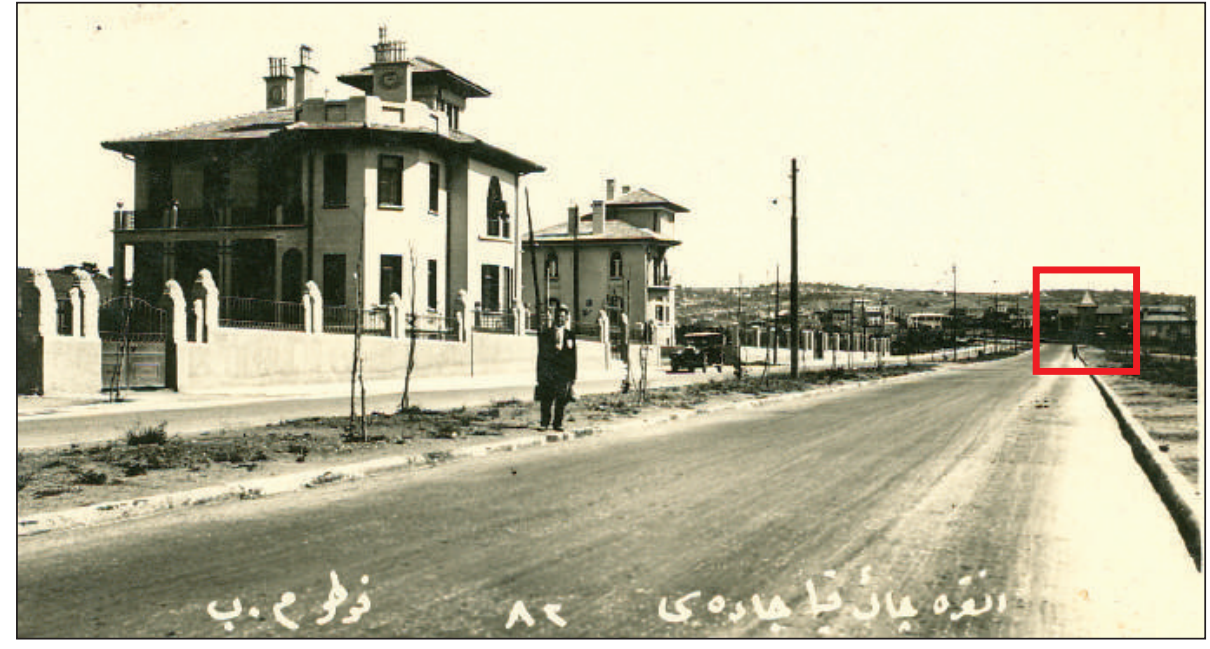

Figure 20A. Fevzi Paşa Mansion (Yenişehir). Architect: Arif Hikmet Koyunoğlu.

Date: before 1928. Source: VEKAM Library and Archive, Inventory no: 2480.

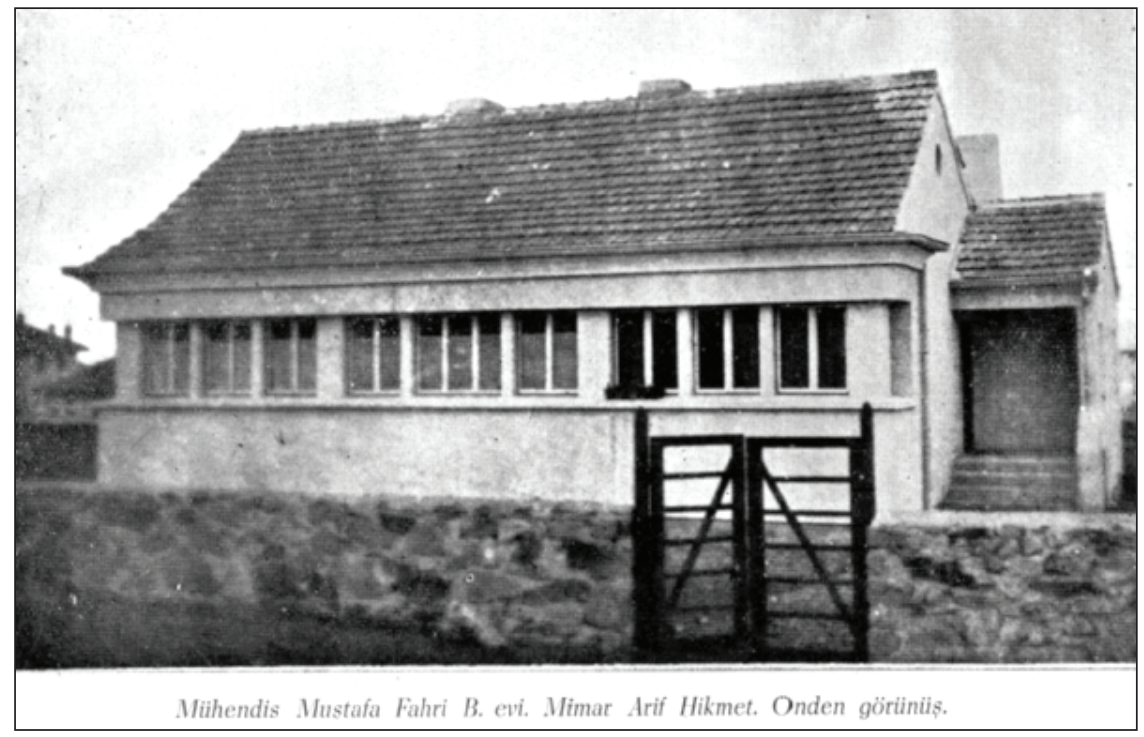

Figure 20B. House of Mustafa Fahri Bey (Yenişehir). Ankara. Architect: Arif Hikmet Koyunoğlu.

Date: 1920s. Source: Arif Hikmet, 1931. 


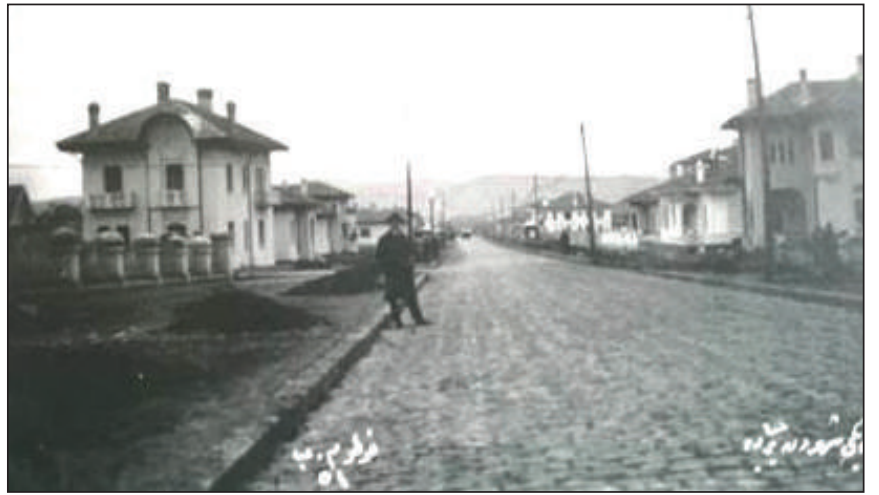

Figure 21 A. Houses (Kazım Özalp (Kazım Paşa, Ziya Gökalp) Street). Architects: A. Kemalettin Bey and Arif Hikmet Koyunoğlu. Date: 1924-25.

Source: Sağdıç, 1994, p.181.

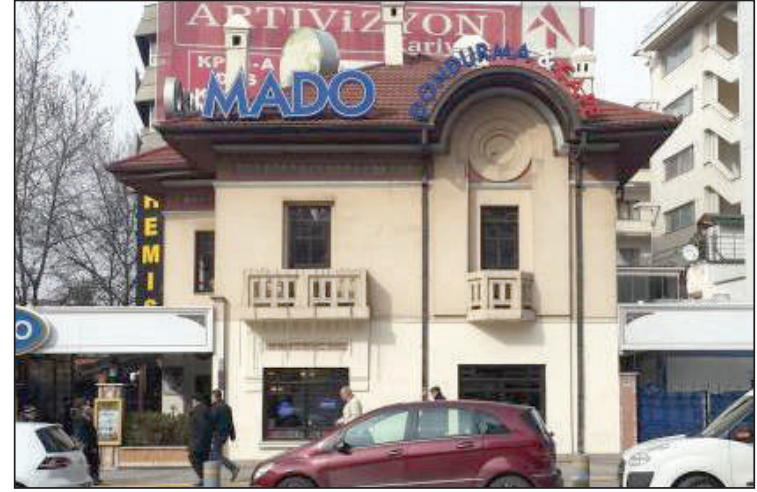

Figure 21B. A House (Ziya Gökalp Street, No: 13). Date: 1924-25.

Photograph by: D. Avcı Hosanlı, 2018.

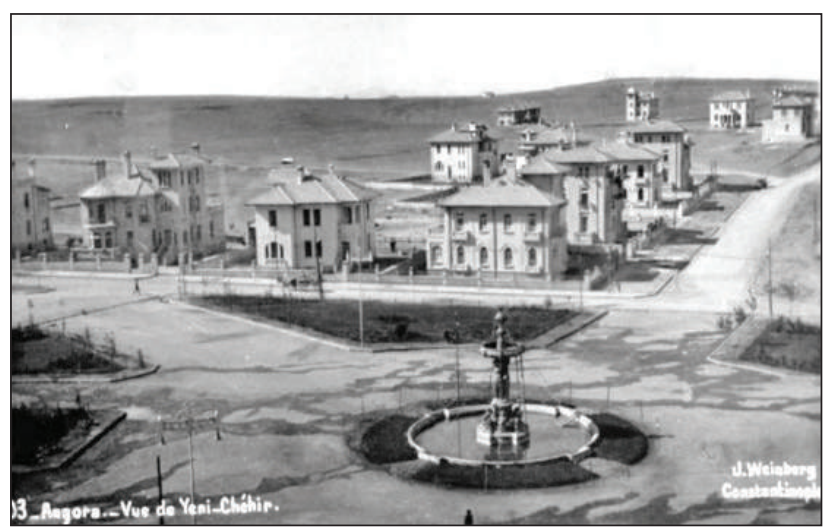

Figure 22A. Houses (Milli Müdafaa Street and Necatibey Street). First row, the second one from the right is the House on the Milli Müdafaa Street at No: 4. Date: 1920s.

Source: Vekam Library and Archive, Inventory no:0038.

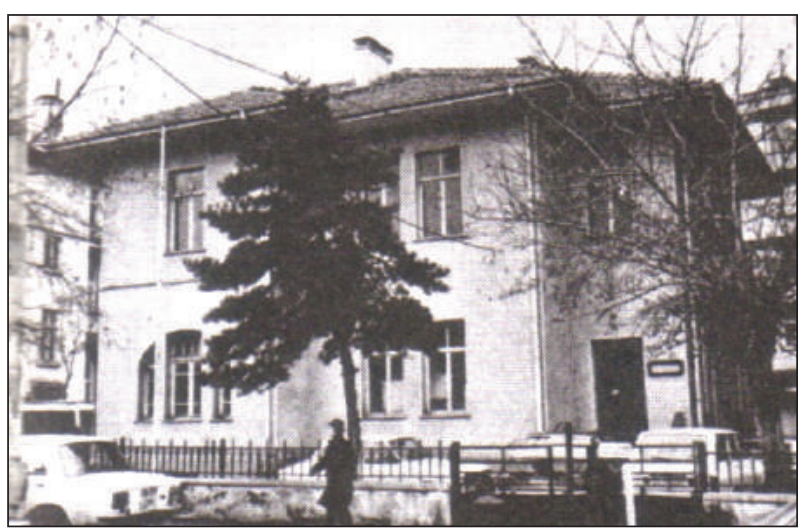

Figure 22B. A House (Milli Müdafaa Street, No: 4).

Date: 1920 s.

Source: Aslanoğlu, 1980, p.305.
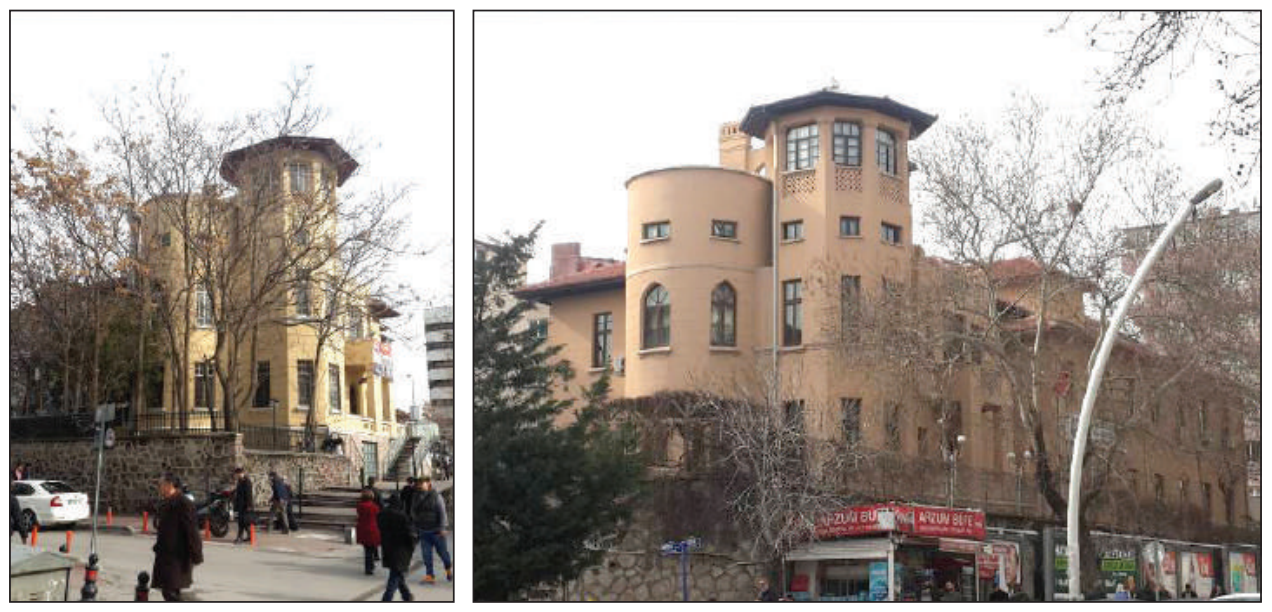

Figure 23A,B. Two VillaType Houses (Necatibey Street). Date: 1920s. Photograph by: D. Avc1 Hosanl, 2018. 
Havuzbaşı Square, which was the main public place of Yenişehir that was constructed in 1927 (Figure 22A). From there Gazi Mustafa Kemal (Atatürk) Boulevard continued towards the Ministeries Quarter that was planned to be constructed in the further southern part of the city (Table I; Figure 1A and 1B), where other housing examples of the period were constructed. The square connected the three important streets shaping Yenişehir, i.e. Gazi Mustafa Kemal (Atatürk) Boulevard running in the north-south direction, and Kazım Özalp (later Ziya Gökalp) and Necatibey (previously Gazi Mustafa Kemal) Streets on the eastern and the western sides of the square. Around all these main routes and the streets in between, the construction of single houses rapidly increased (Figure 21A and 21B; 22A and 22B).

Yenişehir developed fastly to house one-twelfth of the population of Ankara soon, and in ten years, 2000 single houses were constructed in this part of the city according to the development plans (Aydin et al., 2005, p. 441). Even though the area had been envisioned as composed of two-storey modest houses, such as the houses on Kazım Özalp (Ziya Gökalp) Street (Figure 21A and 21B), villa type houses were also constructed in Yenişehir as a result of land speculations.

Some of the known private houses around Yenişehir are known by their owners' names. On Mithatpaşa (İsmetpaşa) Street, the house of Deputy Necati Uğural (or bureaucrat Sait Bektimur; probably both were owners) was built (Figure 24B). Other known houses include those on the opposite direction of Ziya Gökalp Street, across the Havuzbaşı Square, on Necatibey Street (Figure 22A and 22B). At the southeastern corner of Havuzbaşı Square, the house of Minister of Interior Affairs Cemil Uybadin was built (Figure 19). On Necatibey Street, two large villas, similar in appearance, mass, and style to the Cemil Uybadin House, were constructed (Figure $23 \mathrm{~A}$ and 23B). Other than these three mansions, many single private houses were constructed on Necatibey Street and on its intersection with Milli Müdafaa Street. The houses in wide courtyards can be recognized in the contemporary postcards and the photographs of these streets (Figure 22A). The known ones include the house on Necatibey Street (Figure 24A) and the one on Milli Müdafaa Street (Figure 22B), both quite close to and with visual perception of Havuzbaşı Square. The other three houses next to the house on Milli Müdafaa Street can also be recognized in the postcards (Figure 22A).

The housing production in Yenişehir mostly consisted of such single detached houses in large gardens. Nonetheless, the examples of apartments were also seen here during the 1920s, generally constructed as housing projects of public institutions to be used as lodgings for their staff. For example, the Lodgings of the Agriculture Bank, designed by Mongeri, were built on Adakale Street. These were consisted of five single houses with three different types, all with basement floors and two storeys above, together with a small apartment constructed as the first of its type in

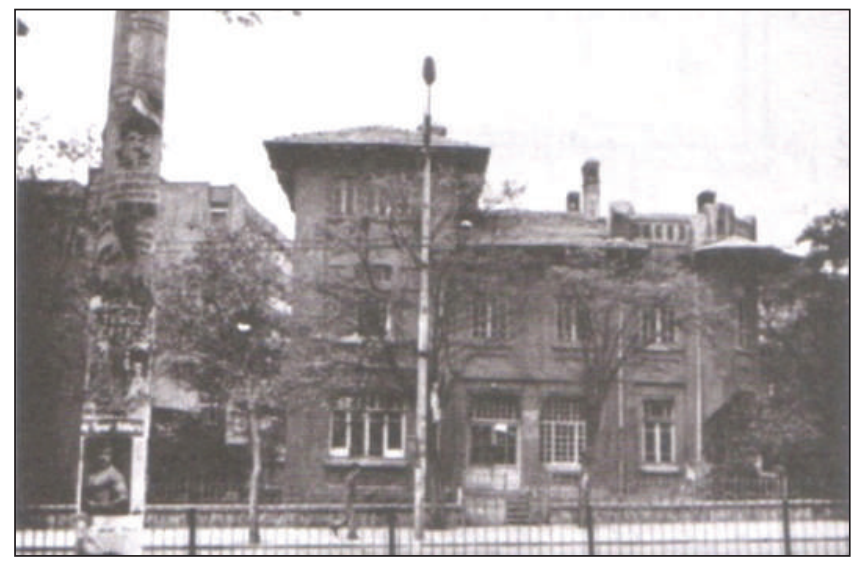

Figure 24A. A House (Necatibey (previously Gazi Mustafa Kemal) Street, No: 9). Date: 1920s.

Photograph date: Unknown. Source: Aslanoğlu, 1980, p. 306.

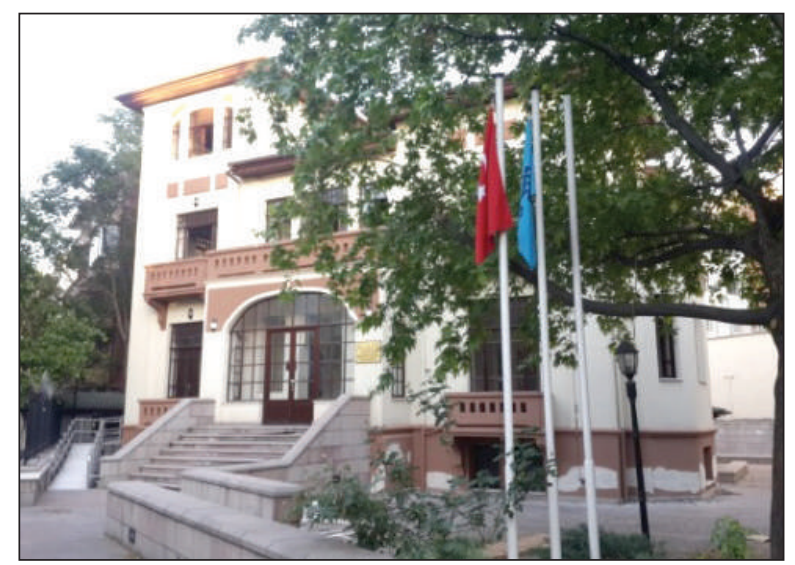

Figure 24B. Necati Uğural or Sait Bektimur House (Mithatpaşa (İsmetpaşa) Street). Date: before 1927. Photograph by: D. Avc1 Hosanlı, 2018. 
the new city, called Altılı Tip (Six-Unit Type) that had six separate units (Figure 25) (Aslanoğlu, 2010, pp. 385-387). Like the single houses, the apartments in the area were also constructed as detached from their surroundings and in large gardens and courtyards. As such, the newly formed built environment in the new city was radically different in its spaciousness from the crowded old city of the period. Although the area was still not densely built in this decade, the spread of the city continued at the time from Yenişehir to further south, leading to the President's House in the Çankaya vineyards, and new houses began to be constructed especially along Gazi Mustafa Kemal (Atatürk) Boulevard (Figure 26).

\section{The Formation of Shed-Houses}

The traditional residential areas of the old city and the vineyards transformed and the new city was formed to answer the contemporary needs during the 1920s; however, this could not prevent the formation of shed housing as part of the unplanned areas of Ankara as the newly developing planned areas were shaped by disregarding the needs of the poorer population who came to the new capital city (Table I). As Ankara became the capital city, the immigration of Anatolian villagers there significantly increased. These villagers were poor after years of war, and they were looking for working opportunities in the new capital city. In the face of the limited accommodation means in the new capital city, investments for sheltering the newcomer workers and their families provided to be insufficient. Unable to afford renting old houses or constructing new ones, illegal constructions would become a self-help method as the immigrants in Ankara tried to solve their sheltering problems in the surroundings of the old city towards the north (later known as Altındağ) and the northwest (Akköprü swamps, plantation fields), which were considered unsuitable for planned constructions, thus empty and unsupervised as excluded from the ongoing plans, providing available grounds for the development of unplanned housing (Şenyapilı, 2004, pp.74-75). Temporary dwellings, which were set on treasury property or the property of others, thus started to appear, and soon defined as shed-houses (barakas as they were called) ${ }^{15}$ (Cengizkan, 2009, p. 46).

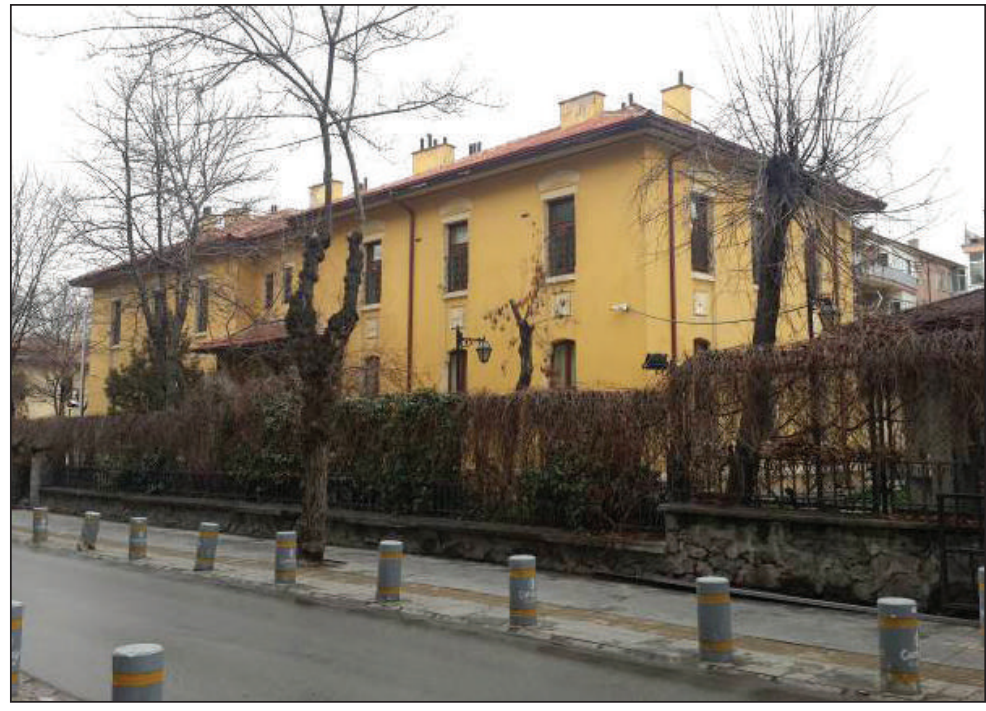

Figure 25. Lodgings of the Agriculture Bank (Ziraat Bankasi). The Apartment is known as the Altılı Tip (Six-Unit Type). Architect: Giulio Mongeri. Date: 1925-26. Photograph by: D. Avc1 Hosanl, 2018.

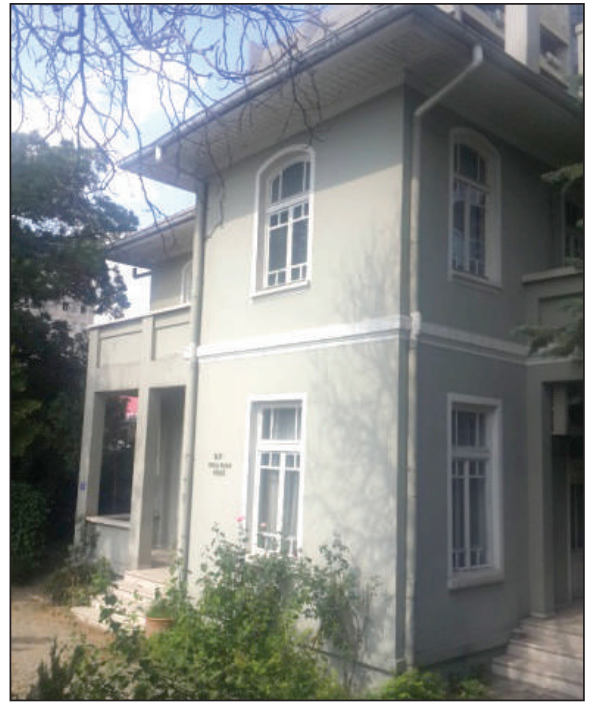

Figure 26. Celal Bayar Mansion (Yenişehir). Architect: Arif Hikmet Koyunoğlu. Date: 1920s. Photograph by: D. Avc1 Hosanlı, 2017.

15 Shed-houses were still very few in number and their settlement areas were considerably small during the 1920s to form "squatter-neighborhoods". The development into squatter-neighborhoods occurred after the 1930s. According to a census in 1935, there were 822 shed houses around the Old City, 23 around Yenișehir, 17 in Cebeci and 75 in the vineyards, making a total of 937 shed houses. Even in 1935, they formed only $5 \%$ of the housing areas in the city (Aydin et al., 2005, p.439). 
This started to create a significant problem to such an extent that Jansen included in his 1927 plan a "worker neighborhood" in Akköprü, although it was not realized because the financial income of the poorer population was not enough to live in this neighborhood, the organization for the realization of this project could not be provided, and land prices became very high to carry out new constructions in this area (Şenyapıll, 2004, p.75) (Figure 27B). The construction of shed-houses was carried out with residual materials remained from the constructions in the city (Aydin et al., 2005, p.445). According to sociologist Behice Boran, it was also possible to see the lowest class of state employees among those who resided in such places, as those "at the first step of their career, such as police officers and village tax collectors, could be seen [to reside] in the mud-brick-house neighborhoods" (Boran, 1941, p.16; Aydın et al., 2005, p.501).

One of the places where shed-houses initially appeared was the neighborhood of Cebeci, which took its name from a settled Cebeci Hearth (Cebeci Ocağl $)^{16}$ here in the late Ottoman period, located in an area close to the railroad built in 1892 in order to transfer the weapons produced easily. Apart from the hearth, the area had been scarcely settled before Ankara's transformation into the capital. There were only a few village houses, and the dwellers of Ankara visited the wide and empty region only for outdoor activities during summers (Şenol-Cantek and Z1rh, 2014, p.158). As a site beyond the boundaries of the old city, but still close to the railroad and located in the east of the developing new city, Cebeci became an outer zone of housing as Ankara transformed into the capital city, meeting the accommodation needs of the newcomers to the city without a planned process (Figure 27A). The newcomers to Ankara, or the homeless villagers who lived in the open, found Cebeci a desirable settlement area for its closeness to both parts of the city. In time, Cebeci became preferable and developed in-line with the developments in Yenişehir. For example, one of the important documents at the State Archives regarding the area is a proposal given by Urfa Deputy Refet Bey about the improvement of the road that connected Samanpazar1 and Cebeci in 1926, and another document dated to 1928 is about the issue of licenses for the neighborhood (ŞenolCantek and Zirh, 2014, p.149).

At the end of the 1920s, despite all the efforts to stop unplanned production of residential architecture, Cebeci had already developed with one-storey shed-houses together with only a few planned ones. The Development Management Committee (Imar İdare Heyeti), with the regulation dated June 11, 1929, and numbered 1504, initiated a demolition process of shed-houses (ŞenolCantek and Zirh, 2014, p.150). However, this type of

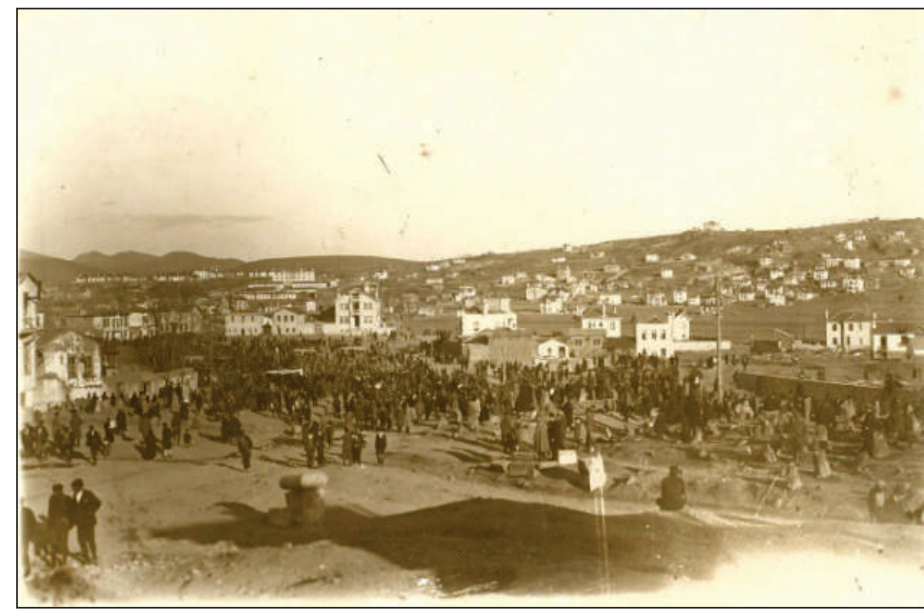

Figure 27A. Planned and Un-Planned Housing Development (Cebeci). Source: VEKAM Library and Archive, Inventory no:1992.

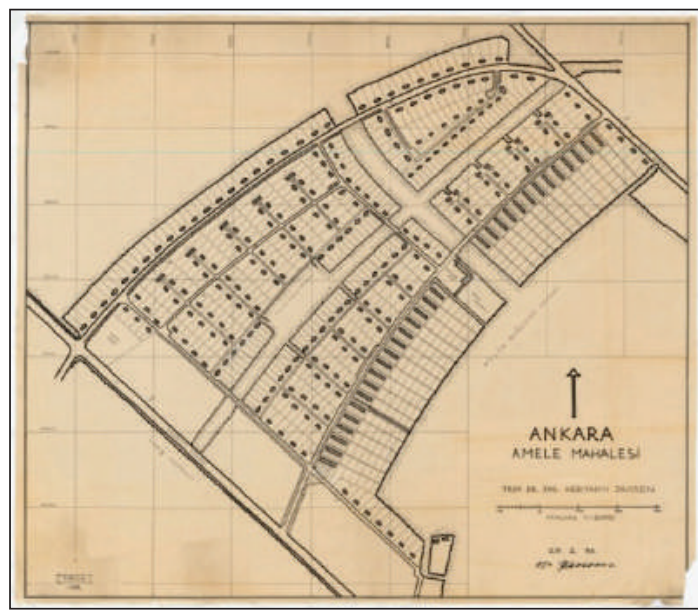

Figure 27B. Laborer Neighborhood (Amele Mahallesi) (Akköprü). Designed by Hermann Jansen. Date: 1936. Source: Akköprü, 1936.

16 For further information on Cebeci Ocağ $\mathrm{at}$ area, which was a weapon production and repair house for the Yeniçeri army, comprised of soldiers from "kapıkulu" sects, see: Şenol-Cantek and Zırh, 2014, p.147. 
housing production still continued around Cebeci and İncesu (at the southwest of Cebeci and the east of Sihhiye) after 1930. The Cebeci area had started to form as a shedhousing neighborhood, but soon became a part of the old city with the construction of Talatpaşa Boulevard, and was connected to the new city with the increased housing production towards the south. ${ }^{17}$ By means of its location, and some fortunate construction of planned new housing close to Yenişehir, Cebeci's unplanned housing problem could be solved in time to some degree.

\section{Conclusion}

The housing production in Ankara during the 1920s was shaped in the context of the building of the new capital city of the new Turkish Republic. The construction of public spaces worthy of a modern capital was simultaneously realized by the provision of required housing in the face of the fast increase in population. The housing problem was partially overcome with the use of the existing traditional houses in the old city and the vineyards as they were rented or sold, and thus altered. The existing neighborhoods in the old city began to transform with widened and rehabilitated streets as well as the renewal of traditional houses to adapt to new technological and living requirements. New blocks were also built within the old city with the expropriation of lands in fire areas, empty blocks, previous swamp or cemetery areas, and in the lands towards the Train Station and to the south. Additionally, the vineyards in the north and south of the old city also began to transform as the vineyard-houses were rented, settled in and upgraded with technological utilities by the new owners. Nonetheless, the provision of new housing became one of the most important priorities as the poor and neglected traditional residential architecture of the city could not provide enough and sanitary shelter. This led to new housing constructions in the old city in empty or re-organized lands, and eventually to the building of the new city-Yenişehir that was envisioned in the middle of the decade, and constructed in bare lands in the south of the old city, past the railroad, setting the main development direction of Ankara for the following decades. Due to the insufficient housing for the increasing population despite the housing construction in the old city and the new city, shed-houses (barakas) also began to appear in the unplanned outer areas of the city.

Thus, the residential architecture produced by public and private initiatives began to define the built environment of the new capital, processed in relation to the planning efforts that attempted to shape its urban growth. The original boundaries and character of the historical center and the vineyards transformed in the process, although the old city continued to be the main settlement zone of Ankara during the 1920s. By the planning efforts that directed the development of the city towards the south along the newly opened Gazi Mustafa Kemal (Atatürk) Boulevard, the new city was formed as a new settlement zone in the south to accommodate residential together with public functions.

As pointed out in the exemplary cases in this paper, the new housing of the 1920s was realized as single houses or apartments, whose types were shaped in direct relation with the spatial characteristics of these old and new settlement zones.

Due to the high demands for residences in the old city while the areas for new construction were limited as a result of its geographical conditions and crowdedness, both houses and apartments constructed there were mostly attached to and some were semi-detached from the neighboring buildings in the central commercial areas provided by the division of lots, and detached ones could only be seen towards its periphery in hitherto unsettled, newly developing, empty regions. Additionally, more apartments were constructed in the old city than in any other part of Ankara at the time to answer the need in less space; ${ }^{18}$ and the apartment-complexes emerged there as the most extravagant housing productions of the decade in both physical and technological terms (Table

17 The stories and novels written after the 1920s also show that Cebeci became part of Yenişehir in time. In the story of Haşmet Gülkokan by Esandal, for example, the protagonist of the novel, Haşmet Bey, is happy to be living in Cebeci, and conscious of the development in Yenişehir and its effect on the surrounding neighborhoods. At one point in the story, he says: "Thank God our Cebeci has become like Yenişehir" (Esendal, 1971, p.194).

18 The construction of apartments could also be related to the preferences of the new inhabitants who were mainly the bureaucrats of the new state, requiring further analysis of the contemporary population's social profiles. See the discussion on "the Life Style of the Republican Bourgeoisie" during the 1920s in: Nalbantoğlu, 1981, pp.27-30. 
II). The crowded central neighborhoods of the old city were thus consisted of mostly unhealthy housing with narrow, stuffy, and dark buildings, either without or with small courtyards that could only function as light and ventilation shafts (Yavuz, 2000, p.237).

The housing production was all new in the new city, and the prototypical type of housing there was mainly formed of independent, single houses in large gardens, which wiere designed for single families. The new city was built up with these houses with the exception of a few lodgings owned by institutions in the area. Thus, the new residential fabric of the new city mostly consisted of single, detached, garden-houses-either modest, small, and one-two-storeys high, or two-three storeys high villatype houses. Although less in number, there were also

Table II: Housing Types in Ankara during the 1920s.

\begin{tabular}{|c|c|c|c|}
\hline \multicolumn{4}{|c|}{ TRADITIONAL HOUSING } \\
\hline existing traditional houses & \multicolumn{2}{|c|}{ vineyard houses } & $\begin{array}{l}\text { new houses built in } \\
\text { traditional ways }\end{array}$ \\
\hline \multicolumn{4}{|c|}{ NEW HOUSING } \\
\hline $\begin{array}{l}\text { single houses } \\
\text { in the Old City - Ulus } \\
\text { - adjacent / attached } \\
\text { - semi-detached } \\
\text { - detached }\end{array}$ & $\begin{array}{l}\text { apartments } \\
\text { in the Old City - Ulus } \\
\text { *low-rise } \\
\text { - adjacent / attached } \\
\text { - semi-detached } \\
\text { - detached } \\
\text { - apartment-complexes }\end{array}$ & $\begin{array}{l}\text { *modest, small, } \\
\text { one-two storey high } \\
\text { *villa-type houses } \\
\text { two-three storey high }\end{array}$ & $\begin{array}{c}\text { apartments } \\
\text { in the New City - Yenișehir } \\
\text { *low-rise } \\
\text { - all detached }\end{array}$ \\
\hline \multicolumn{4}{|c|}{ SHED-HOUSING } \\
\hline \multicolumn{4}{|c|}{ in un-planned areas around the Old City; Akköprü, Cebeci } \\
\hline
\end{tabular}


three or four-storey apartments in the new city, still all were detached and in large gardens (Table II). ${ }^{19}$

With reference to the total number of houses and apartments provided until the $1930 \mathrm{~s},{ }^{20}$ the continuing major role of the old city in housing the new capital city during the first decade of the Republic could be determined while the area of the new city appears as a secondary yet noteworthy developing part of the city for housing provision. The transformation of the old city with interventions in its urban context to provide new accommodation places, and the formation of the new city with the construction of new residences in the previously empty lands, most significantly aimed at answering the contemporary housing need but also attempted to provide an urban development in Ankara in accordance with the modernization process of the new state. This required the controlled growth of the city that was put into practice in the early years of the Republic with Lörcher's plans, and the residential architecture of the 1920s was accordingly realized as a significant part of the creation of a modern built environment in Ankara. Nonetheless, despite the significant change that the new capital city witnessed during its first decade as a result of these undertakings in planning and housing production, the beginning of shed-housing formation in the unplanned areas of the city at the time signaled the still existing problems in urban development, which would become more serious in later decades. In addition, the contemporary vision of a "garden city" for the new capital city ${ }^{21}$ would prove to be unproductive in time with the continuous increase in the population of Ankara, resulting in the dominance of apartment blocks in its future urban context.

\section{References}

Acar, E. (1975). Ankara: Osmanlı Anadolu kentinde mülkiyet/doku ilişkileri. (Unpublished Master's Thesis). METU, Ankara.

Akcan, E.(2009). Çeviride modern olan, şehir ve konutta TürkAlman ilişkileri. İstanbul: Yapı Kredi.

Akköprü [plan]. (1936). Architekturmuseum TU Berlin. Retrieved from http://architekturmuseum.ub.tu-berlin.de/ index.php? $\mathrm{p}=79 \&$ Daten $=158827$.

Aktüre, S. (1987). 19. yüzyıl sonunda Anadolu kenti mekansal yapı çözümlemesi. Ankara: ODTÜ Mimarlık Fakültesi.

Al, M. (2011). Kentte bellek yıkımı ve kimlik inşası-palimpsest: Ankara Atatürk Bulvarı bağlamında bir inceleme. İdeal Kent, 2(4), 22-36.

19 The preference for such an environment continued in the later decade. In 1935, the Ulus newpaper asked its readers about their suggestions for solving the still-continuing housing problem in Ankara. One of the questions asked whether the housing for state officers should be single houses in gardens, or apartments; and if they were to be single garden houses as either adjacent on one side to or detached from other houses. 17 answers to this survey were published in the newspaper, including those by Jansen, whose plan of 1927 had already begun to be implemented, Italian architect Vietti Violli, French engineer Kazalonga, and French architect Laprade, who were working in Turkey at the time, and by some Turkish architects, urban-planners, initiators of housing-cooperatives, a woman deputy, and known intellectuals of the era. According to most of them, state officers' houses should be designed as garden houses. Even though they were desired as separate single houses, the answers suggested that adjacent ones could be "bearable". Only one person suggested the use of apartments for the housing problem, adding that singles, women and students could live in apartments whereas families should live in garden-houses. Architect Burhan Arif Bey, on the other hand, suggested that apartments should be banned all over the country. The supporters of single-garden houses related their suggestions with a number of reasons such as the relation of Turkish people with land, the provision of a sanitary lifestyle, Turkish people's not being accustomed to apartment-lifestyle, and the related provision of wide green areas within the city. Garden houses were desired as single detached houses, and adjacent houses could only be accepted if the production and the final cost would be cheaper. Only architect B. E. Asim Bey suggested adjacent single houses for the functional use of streets, thinking in an urban-scale design approach. See: Ulus, November 28, 1935 and Karinca Dergisi, A.2, March 1936, cited in Tekeli, 2012, p.82-83.

20 As seen from the distribution of accommodation in Ankara in the Statistical Yearbook of 1935-36, which contains the first census of buildings, the residential architecture constructed until the 1930s was mainly consisted of single houses in the old city, together with few numbers of apartments. The vineyards were also formed of single houses, together with only one apartment noted to exist. In the new city, the number of apartments reached almost to one third of the number of single houses. In Cebeci, which became a developing part of the new city, on the other hand, single houses were again significantly more in number than apartments. In total, there were 15.879 single houses and 351 apartments in Ankara in 1935. It is seen that most of the single houses were in the old city ( $72 \%$ of the total), while those in other parts of the city formed a lesser amount ( $2 \%$ in the new city, $6 \%$ in Cebeci and $17 \%$ in the vineyards). As seen from the data, half of the apartments were located in the old city (52\%), while they also reached a significant number in Yenişehir (39\%), and lesser in Cebeci (4\%). See: Aydın et al., 2005 , p. 440.

21 Aslanoğlu stated that there were less apartments than houses constructed at the time because the number of population was not high enough to require them. See: Aslanoğlu, 2001, pp.43-44. Similarly, Balamir stated that "the dominant view about apartments in the early Republican period was negative both for the public and the professionals. This had, most of all, objective reasons. [At the time], there was neither the need nor the necessary capital, materials and technique for apartment construction. There were just a few people who could afford to get the required iron and cement and undertake such a high-priced endaevor in a suitable land." See: Balamir, 1994, p.29. 
Altan Ergut, E. (2005). Ankara 'Bankalar Caddesi' ve ötesi. Modernleşme sürecinde Ankara ve Cumhuriyet Kentleri, 31, 28-29.

Altan Ergut, E. (2014). Değerlendirme. In N. Bayraktar (Prep. by) Sivil mimari bellek-Ankara-1930-1980: tarih yazımında sivil mimarlık çalıştay notları. (pp. 95-105). Ankara: VEKAM.

Arif Hikmet. (1931). Müh. Mustafa Fahri Bey Evi. ARKİTEKT. 1931/1931-5, 154.

Aslanoğlu, İ. (2010). Erken Cumhuriyet dönemi mimarlı̆̆ 19231938. İstanbul: Bilge Kültür Sanat.

Atay, F.R. (1969). Çankaya. İstanbul: Doğan Kardeş.

Aydın, S., Emiroğlu, K.,Türkoğlu, Ö. ve Özsoy, E. D. (2005). Küçük Asya'nın bin yüzü: Ankara. Ankara: Dost Kitabevi.

Bademli, R. (1985). 1920-1940 döneminde eski Ankara’nın yazgısını etkileyen tutumlar. Mimarlık, 2-3, 10-16.

Balamir, M. (1994). Kira evinden kat evlerine apartmanlaşma: bir zihniyet dönüşümü tarihçesinden kesitler. Mimarlık, 260, 29-33.

Batuman, B. (2017). Ankara'da Cumhuriyet dönemi konut mimarlığının gelişimi üzerine bir dönemleme denemesi. In N. Bayraktar (Prep. by) Sivilmimaribellek Ankara,1930-1980 (pp.11-52). Ankara: VEKAM.

Batur, A. (2003). M. Vedad Tek: kimliğinin izinde bir mimar. İstanbul: Yapı Kredi Kültür Sanat.

Benevolo, L. (1971). History of modern architecture. Cambridge, Massachusetts: M.I.T.

Bertram, C. (2008). Imagining the Turkish house: collective visions of home. Austin: University of Texas Press.

Boran, B. (1941). Modern şehir örneği. Yurt ve Dünya, 6, 9-17.

Bozdoğan, S. (2012). Modernizm ve ulusun inşası: erken Cumhuriyet Türkiyesinde mimari kültür. İstanbul: Metis.

Cebeci [photograph]. (1920s). Ankara Photograph Postcard and Engraving Collection (1992). Koç University VEKAM Library and Archive, Ankara.

Cengizkan, A. (2002). Bağ Evi'nden Villa’ya: Ankara Keçiören bağ evleri ve kent konutu tipolojisinde dönüşüm. In A. Cengizkan (Ed.) Modernin saati: 20. yüzyılda modernleşme ve demokratikleşme pratiğinde mimarlar, kamusal mekan ve konut mimarliğı (pp.119-142). İstanbul: Boyut Yayın.

Cengizkan, A. (2004). Ankara’nın ilk planı: 1924-25 Lörcher Planı, kentsel mekan özellikleri, 1932 Jansen Planina ve bugüne katkıları, etki ve kalıntıları. Ankara: Ankara Enstitüsü Vakfı.

Cengizkan, A. (2009). Ankara 1923-1938: Çağdaş bir ulus devletin modern ve planlı başkenti / Ankara 1923-1938: The modern and planned capital of a contemporary nation state. In E. Işın (Ed.) Ankara: kara kalpaklı kent 1923-1938 / Ankara: City of the black calpac 1923-1938 (pp.17-65). İstanbul: İstanbul Araştırmaları Enstitüsü.
Çankaya [photograph]. (1924). Ankara Photograph Postcard and Engraving Collection (0216). Koç University VEKAM Library and Archive, Ankara.

Dinçer, G. (2014). Ulus'tan Samanpazarı'na Anafartalar Caddesi'nin öyküsü. İdeal Kent, 11, 36-60.

Dündar, C. (Ed.) (2007). Özel arşivinden belgeler ve anılarıyla Vehbi Koç. İstanbul: Doğan Kitapçılık.

Esendal, M. Ş. (1971). Ev ona yakıştı. Ankara: Dost.

Esin, T. and Etöz, Z. (2015). 1916 Ankara yangını: felaketin mantığı. İstanbul: İletişim.

Foundation Houses [photograph]. (1928). Ankara Photograph Postcard and Engraving Collection (1007). Koç University VEKAM Library and Archive, Ankara.

Galip, M. (1926). Ankara evleri. Muallimler Birliği Mecmuası, $8,354-359$.

Gazi Mustafa Kemal (Atatürk) Boulevard [photograph]. (1930). Ankara Photograph Postcard and Engraving Collection (1516). Koç University VEKAM Library and Archive, Ankara.

Gündoğdu [photograph]. (1920s). Ankara Immovable Cultural Property (TKV0107). Koç University VEKAM Library and Archive, Ankara.

Günel, G., Kılcı, A. (2015). Ankara Şehri 1924 Haritası: eski bir haritada Ankara'yı tanımak. Ankara Araştırmaları Dergisi, 3(1), 78-104.

Işıklar Street [photograph]. (1925). Ankara Photograph Postcard and Engraving Collection (2140). Koç University VEKAM Library and Archive, Ankara.

İnce Güney, Y. and Wineman, J. (2008). The evolving design of $20^{\text {th }}$ century apartments in Ankara. Environment and Planning B: Planning and Design, 35, 627-646.

Keçiören [photograph]. (1928). Ankara Photograph Postcard and Engraving Collection (2451). Koç University VEKAM Library and Archive, Ankara.

Koyunoğlu, A.H. (1929). Ankara evleri. Türk Yurdu, 3(23), 4647.

Kömürcüoğlu, E. (1950). Ankara evleri. İstanbul: İstanbul Matbaacilık.

Kuruyazıc1, H. (2008). Osmanlidan Cumhuriyet'e bir mimar: Arif Hikmet Koyunoğlu. anılar, yazılar, mektuplar, belgeler. İstanbul: Yapı Kredi.

Mamboury, E. (1933). Ankara: Guide touristique. Ankara: Ministère Turc de l'intérieur.

Mıhçığlu Bilgi, E. (2010). The Physical evolution of the historic city of Ankara between 1839 and 1944: a morphological analysis. (Unpublished Doctoral Dissertation). METU, Ankara.

Nalbantoğlu, G. (1981). An architectural and historical survey on the development of the 'apartment building' in Ankara, 19231950. (Unpublished Master's Thesis). METU, Ankara. 
Ortaylı, İ. (2014). Ankara'nın eski bağevleri. İdeal Kent, 11, 112118.

Özgönül, N.and Gökçe, F. (2001). Ankara'da kaybolan kültür varlıklarımız; bağ evleri. In Y. Yavuz (Ed) Tarih içinde Ankara II, Aralk 1998 Seminer Bildirileri (pp.269-288). Ankara: ODTÜ Mimarlık Fakültesi.

Öztürk, H. H.(2007). Tarihi ve kültürel çevrenin korunmasında sivil toplumun rolü: Hamamönü örneği. (Yayımlanmamış Yüksek Lisans Tezi). Ankara Üniversitesi, Sosyal Bilimler Enstitüsü, Sosyal Bilgiler Çevre Bilimleri Anabilim Dalı, Ankara.

Poyraz, U. and Gündoğan, M.Ö. (2014). Tarihsiz ve talihsiz bir dönüşüm: cazibe merkezi olarak Hamamönü. İdeal Kent, $11,70-88$.

Sağdıç, O. (Ed.) (1994). Ankara posta kartları ve belge fotoğrafları arşivi kataloğu. Ankara: BELKO.

Sarığlu, M. (2001). Ankara bir modernleşme öyküsü (19191945). Ankara: T.C. Kültür Bakanlığı.

Sözen, M. (1984). Cumhuriyet dönemi Türk mimarliğı (19231983). Ankara: Türkiye İş Bankası Kültür Yayınları.

Şenol Cantek, F.and Zırh, B. C. (2014). Bir semt monografisine doğru: Cebeci'ye bakmak. İdeal Kent, 11, 138-172.

Şenyapıl1, T. (2004). Baraka"dan gecekonduya Ankara'da kentsel mekânın dönüşümü:1923-1960. İstanbul: İletişim.

Tankut, G. (1993). Bir başkentin imarı: Ankara 1929-39. Ankara: ODTÜ.

Tekeli, İ. (2012). Türkiye'de yaşamda ve yazında konutun öyküsü (1923-1980). İstanbul: Tarih Vakfı Yayınları.
The Hisarönü Quarter [photograph]. (1930). Ankara Photograph Postcard and Engraving Collection (1284). Koç University VEKAM Library and Archive, Ankara.

Tunçer, M. (2011). Ankara Sulu Han (Hasan Paşa Hanı), Tahtakale çarşısı ve çevresi: 1929 yangını öncesi. İdeal Kent, 4, 38-62.

Tunçer, M. (2014). 20. Yüzyılın başlarında Tahtakale, Karaoğlan Çarşısı ve Taşhan'dan Ulus Merkezi'ne dönüşüm. İdeal Kent, 11, 18-36.

Yavuz, A. (2001). İzzet Aykurt Evi: bir Erken Cumhuriyet Dönemi konutu. In Y. Yavuz (Ed.) Tarih İçinde Ankara II, Aralk 1998 Seminer Bildirileri (pp.289-327). Ankara: ODTÜ Mimarlık Fakültesi.

Yavuz, Y. (2000). 1923-1928 Ankarası'nda konut sorunu ve konut gelişmesi. In Ayşıl Tükel Yavuz (Ed.) Tarih İçinde Ankara Eylül 1981 Seminer Bildirileri (pp.233-252). Ankara: TBMM.

Yavuz, Y.(2001).Ankara-ÇankayadakibirinciCumhurbaşkanlığ Köşkü. In Y. Yavuz (Ed.) Tarih İçinde Ankara II, Aralık 1998 Seminer Bildirileri (pp.341-413). Ankara: ODTÜ Mimarlık Fakültesi.

Yenişehir [photograph]. (1920s). Ankara Photograph Postcard and Engraving Collection (0038). Koç University VEKAM Library and Archive, Ankara.

Yenişehir [photograph]. (1920s). Ankara Photograph Postcard and Engraving Collection (2480). Koç University VEKAM Library and Archive, Ankara. 